\title{
LOS INGRESOS EXTRAORDINARIOS DEL REINO DE GALICIA EN EL SIGLO XV ${ }^{1 *}$
}

\section{EXTRAORDINARY INCOME OF THE KINGDOM OF GALICIA IN THE FIFTEENTH CENTURY}

\author{
AMPARO RUBIO MARTÍNEZ \\ Universidad Lumière Lyon 2
}

\begin{abstract}
Resumen
Estudio de los impuestos extraordinarios que se recaudan en el reino de Galicia durante todo el siglo XV. En primer lugar se presta atención a la recaudación de los pedidos reales durante los reinados de Juan II y Enrique IV, para pasar después a analizar otras formas de recaudación de tributos extraordinarios como la contribución de la Hermandad y su sustitución, a partir de 1498, por los servicios extraordinarios aprobados por las Cortes del reino.
\end{abstract}

\section{Palabras clave}

Hacienda Real, siglo XV, pedidos reales, servicios extraordinarios, Contribución de la Hermandad.

\begin{abstract}
Study of the extraordinary taxes that are levied in the kingdom of Galicia during the fifteenth century. First attention is given to the collection of actual orders during the reigns of John II and Henry IV, then move on to explore other ways of collecting taxes and extraordinary contribution of the Brotherhood and its replacement, from 1498, for extraordinary services approved by the Cortes of the kingdom.
\end{abstract}

\section{Keywords}

Real Hacienda, fifteenth century, royal orders, extra services, Contribution of the Brotherhood.

${ }^{1}$ Recibido/Received 17.07.2009. Aceptado/Accepted 23.11.2009

* El presente artículo se inscribe en el marco del proyecto de investigación: "Hacienda real, poder político y sociedad en Castilla (1406-1516)" BHA-2002-03292 dirigido por el Dr. Miguel Ángel Ladero Quesada. La elaboración del trabajo ha contado con la ayuda económica del Ministerio de Educación y Ciencia y de la fundación Caja Madrid en su programa de becas predoctorales.

Abreviaturas utilizadas: AGS (Archivo General de Simancas), CMC (Contaduría Mayor de Cuentas), EMR (Escribanía Mayor de Rentas), Exp de Hac (Expedientes de Hacienda), RGS (Registro General del Sello), CCA (Cámara de Castilla), CED (Libros de Cédulas), RAH (Real Academia de la Historia). 


\section{INTRODUCCIÓN}

El estudio de la recaudación de pedidos reales, contribución de la Hermandad y servicios extraordinarios otorgados por las Cortes del reino, presenta especial interés en el reino de Galicia, sobre todo porque, durante buena parte del siglo $\mathrm{XV}$, la población gallega mostró una clara resistencia al pago de servicios extraordinarios, como consecuencia directa de la pérdida de representación de los procuradores gallegos en las Cortes del reino. ${ }^{2}$ Ahora bien, a pesar de ser este el principal motivo de oposición, no cabe duda de que en la primera mitad del siglo XV se dieron una serie de circunstancias que contribuyeron a acentuar, en mayor o menor medida, la negativa del reino de Galicia al pago de servicios extraordinarios. Entre estos factores juegan un papel especial los privilegios que disfrutaban las instituciones eclesiásticas del reino de Galicia, así como las continuas exenciones fiscales que los reyes concedieron a las ciudades, villas y lugares de la tierra de Santiago. Sabemos, por otra parte, que al menos durante el siglo XV, el reino de Galicia estaba exento del pago de monedas que las Cortes aprobaban junto al pedido, y es posible que dicha exención hubiera contribuido a incrementar la negativa del reino al pago del pedido o servicio extraordinario. ${ }^{3}$ Desde 1406 en adelante, pedidos y monedas quedaban englobados bajo la denominación genérica de "servicios" que las Cortes aprobarían sucesivamente durante los reinados de Juan II y Enrique IV. El reino de Galicia, al estar exento del pago de monedas, continuaría recaudando los servicios extraordinarios bajo la forma de "pedido".

Del mismo modo, nos consta que durante todo el siglo XV, la población de la tierra de Santiago contribuyó con el pago de un servicio extraordinario a la Hacienda arzobispal compostelana, lo que de alguna manera pudo también tener que ver con esta negativa de la población gallega al pago del pedido, sobre todo de aquella

2 Sobre las dificultades que presenta el reino de Galicia al pago de estos impuestos véase GARCÍA ORO, J.: Galicia en los s. XIV y XV. Galicia señorial, vol.I, Pontevedra, 1987, pp. 301, OLIVERA SERRANO, C.: "La ausencia de Galicia en las Cortes del siglo XV" en Galicia en la Edad Media, Madrid, 1990, p. 318, "El pedido de 1455 en el reino de Galicia" en Cuadernos de Estudios Gallegos, Tomo LI, 117 (2004), pp. 363-374., y FERNÁNDEZ VEGA, L.: "Las juntas del reino de Galicia y la recuperación del voto en Cortes" en Compostellanum, vol XXV, núm. 1-4, 1480, pp. 6979. Sobre los servicios extraordinarios votados por las cortes de Castilla durante los reinados de Juan II y Enrique IV, resulta especialmente interesante el manuscrito de la Real Academia de la Historia 9/1784. La documentación que recoge este manuscrito hasta el año 1474, ha sido publicada por C. OLIVERA SERRANO.: Las Cortes de Castilla y León y la crisis del reino (1445-1474). El registro de Cortes, Burgos, 1986, pp. 177-391.

3 OLIVERA SERRANO, C.: "El pedido de 1455...", op cit, p. 364. 
que habitaba en la tierra de Santiago. ${ }^{4}$ En cualquier caso, esta oposición al pago de servicios extraordinarios que algunos autores han documentado hasta 1462, no parece tal, según se deduce del examen detallado de la documentación hacendística del Archivo General de Simancas, que constata la contribución esporádica del reino de Galicia en los repartimientos de pedidos reales, especialmente en la década de los años cuarenta.

No parece necesario insistir en el origen, concepto y naturaleza de los tributos que son objeto de estudio en este trabajo, pues todos ellos han sido analizados con detalle para el conjunto de la Corona de Castilla por el profesor Ladero Quesada. ${ }^{5}$ Las páginas que siguen a continuación ponen de manifiesto, contra lo que la historiografía de los últimos años ha señalado, que el reino de Galicia contribuyó en algunos de los repartos de pedido que se efectuaron en Castilla durante el siglo XV, y por otra parte, pretenden dar a conocer algunos aspectos acerca de la implantación de la Hermandad en dicho reino y del papel que desempeñó en la recaudación de los impuestos extraordinarios, al sustituir desde 1476 en adelante, los tradicionales repartimientos de pedido por una nueva contribución para la que ya no resultaba necesaria la aprobación de las Cortes. La última parte del trabajo se dedica al estudio de los servicios extraordinarios votados por las Cortes del reino a partir del año 1500, que iniciaban un nuevo período fiscal, tras la desarticulación de los órganos centrales de la Hermandad en

${ }^{4}$ Sobre el origen del servicio extraordinario que los habitantes de la tierra de Santiago satisfacían durante el siglo XV a la hacienda arzobispal compostelana y su transformación en un tributo de carácter meramente señorial véase mi artículo "Los servicios extraordinarios de la mesa arzobispal compostelana: la señorialización de un impuesto de origen real en la tierra de Santiago" en Actas del IV Simposio Internacional de Jóvenes Medievalistas, Lorca, 2008 Servicio de Publicaciones de la Universidad de Murcia, pp. 221-240.

${ }^{5}$ Para el estudio del pedido, monedas y moneda forera destacan los trabajos de LADERO QUESADA, M.A.: Fiscalidad y poder real en Castilla (1252-1369), Madrid, 1993, "Cortes de Castilla y León y fiscalidad regia (1369-1429)" en Las Cortes de Castilla y León en la Edad Media, Valladolid, Cortes de Castilla y León, 1988, I, pp. 289-373, La Hacienda Real de Castilla en el siglo XV, La Laguna, 1973, "Ingreso, gasto y política fiscal de la Corona de Castilla desde Alfonso X a Enrique III (1252-1406) en El siglo XV en Castilla. Fuentes de renta y política fiscal, Barcelona, 1982. Del mismo, un trabajo que recopila buena parte de los anteriores, La Hacienda Real de Castilla 13691504, Real Academia de la Historia, 2009. Un estudio detallado sobre el origen y organización de la Hermandad en Castilla y en el reino de Galicia durante el reinado de los Reyes Católicos, y de las cuentas, ingresos y gastos de la denominada contribución de la Hermandad, en los trabajos del mismo autor, La Hermandad de Castilla. Cuentas y memoriales. 1480-1498, Madrid, 2005 y "La Hermandad en Galicia. 1490-1498”, en Cuadernos de Estudios Gallegos, Tomo LII, vol. 118, 2005, pp. 240-287. Sobre los servicios extraordinarios votados en Cortes destacan los trabajos del profesor J. Carretero Zamora, es especial Cortes monarquía, ciudades. Las Cortes de Castilla a comienzos de la época moderna (1476-1515), Madrid, 1988. 
1498, en el que los ingresos derivados de la recaudación de estos servicios se orientarían mayoritariamente a hacer frente a las costosas campañas que la monarquía hispánica había iniciado en el exterior desde mediados de los años noventa.

\section{LA RECAUDACIÓN DE PEDIDOS Y MONEDAS DURANTE EL REINADO DE JUAN II}

La historiografía de los últimos años ha llamado la atención sobre la resistencia que el reino de Galicia presentó al pago de servicios extraordinarios desde finales de la década de los años veinte del siglo XV. ${ }^{6}$ En opinión de algunos autores, esta oposición de la población gallega al pago de servicios aprobados en Cortes habría tenido lugar hasta mediados de la década de los años sesenta y se habría debido, fundamentalmente, a la ausencia de procuradores gallegos en las Cortes del reino. ${ }^{7}$ Tal y como ha señalado César Olivera, fue precisamente en las Cortes de Madrid de 1419, cuando quedaron fijadas las diecisiete villas y lugares que en lo sucesivo deberían acudir a las convocatorias de Cortes, quedando al margen el reino de Galicia. Es posible que fuese en este momento cuando los gallegos habrían dejado de contribuir en los servicios de Cortes, aunque algunos autores sitúen este acontecimiento unos años después, en 1425, cuando el rey Juan II hizo jurar al príncipe don Enrique en Valladolid. ${ }^{8}$

Ahora bien, con independencia del momento en el que el reino de Galicia hubiese perdido su voto en Cortes, lo cierto es que la ausencia de procuradores gallegos en las Cortes del reino tuvo como consecuencia inmediata la oposición del reino al pago de servicios extraordinarios. La primera noticia acerca de la resistencia del reino de Galicia al pago de pedidos procede de las Cortes de Palencia de 1431. Los cuadernos de Cortes relativos a este año señalan que el reino de Galicia no había pagado desde 1429 y de ahí la súplica al rey de que les hiciera pagar lo que les correspondiese, pues de no ser así, la deuda pendiente cargaría sobre los otros reinos de la Corona de Castilla:

\footnotetext{
${ }^{6}$ GARCÍA ORO, J.: Galicia en los siglos XIV y XV. Vol I, op cit, p. 301, OLIVERA SERRANO, C.: "La ausencia de Galicia en las Cortes...", op cit, p. 318 y FERNÁNDEZ VEGA, L.: "Las juntas del Reino de Galicia..." op cit, pp. 69-79.

7 OLIVERA SERRANO, C.: "La ausencia de Galicia en las Cortes..." op cit, p. 318.

8 FERNÁNDEZ VEGA, L.: "Las juntas del Reino de Galicia...”, op cit, p. 71.
} 
"Otrosi suplicamos a V.A que por cuanto, segund somos certificados, en el regno de Gallizia no han pagado en este anno de veynte e nueve que paso lo que les fue repartido e les copo de pagar en el pedido que a Vuestra sennoría fue otorgado en cada uno de los dichos annos, de lo cual a vuestra sennoría viene deservicio e a vuestros regnos recresce mayor cargo, que vuestra alteza quiera proveer en tal manera que lo que así es debido en el dicho rregno de Gallizia del dicho pedido de los dichos annos, sea pagado e cobrado en tal manera que vuestra senoría dello se pueda servir para su necesidad presente de la guerra de los moros, e los otros vuestros pueblos no ayan de lazerar e satisfacer por lo que así los rebeldes no pagan a vuestra alteza" 9

Sin embargo, no parece del todo cierta la idea de que el reino de Galicia hubiese dejado de contribuir definitivamente en los servicios de Cortes, sino que más bien se trató de una contribución esporádica, de manera que sólo en determinados momentos el reino debió hacer efectivo el pago de estos servicios. En este sentido, el examen detallado de la documentación hacendística del Archivo General de Simancas nos permite comprobar que la negativa fiscal del reino de Galicia fue mayor en la década de los años treinta y se fue suavizando desde principios de los años cuarenta.

Efectivamente, durante toda la década de los años treinta, la documentación de la Escribanía Mayor de Rentas no registra noticia alguna sobre los repartos de pedidos en el reino de Galicia, de modo que será preciso esperar a 1442 para disponer de las primeras cifras relativas a dichos repartos. Teniendo en cuenta esta negativa al pago de pedidos, en las Cortes de Madrid de 1435, los procuradores del reino insistían de nuevo en la oposición que presentaba el reino de Galicia y las "Asturias de Oviedo" al pago de pedidos y exigían al rey la contribución de los gallegos con sus obligaciones fiscales. ${ }^{10}$

La ausencia de Galicia en el pago de pedidos se constata hasta el año 1442, pues en el reparto del pedido efectuado en 1440, tampoco contribuyó. El pedido de 1440 asignaba un total de 13.684.429 mrs. para toda la Corona de Castilla, de los cuales, los territorios gallegos debían haber contribuido con $1.790 .590 \mathrm{mrs}$., lo que venía a suponer exactamente el $13 \%$ del total. ${ }^{11}$ En efecto, si examinamos las cuantías asignadas a cada partido fiscal del reino de Galicia este año, observamos que dichas cuantías sumaron un total de 1.790 .590 mrs., exactamente la

9 Cortes de los antiguos Reinos de León y Castilla, Real Academia de la Historia, Madrid, T. III, p. 102, en FERNÁNDEZ VEGA, L.: “ Las juntas del Reino de Galicia...” op cit, p. 75

10 OLIVERA SERRANO, C.: "La ausencia de Galicia en las Cortes..." op cit, p. 318.

11 LADERO QUESADA, M. A.: La Hacienda Real de Castilla...op cit, p. 208. 
mitad de la cuantía global con la que el reino de Galicia debía contribuir, lo que se explica porque este año las Cortes de Valladolid habían otorgado un pedido sin moneda. ${ }^{12}$

En las Cortes de Valladolid de 1442, los procuradores trataron de averiguar las cantidades que los contribuyentes gallegos debían desde 1430 y establecer un sistema de cobro para amortizar la deuda contraída. ${ }^{13}$ Sin embargo, no parece que los procuradores de Cortes hubieran tenido éxito en su intento de saldar las deudas de años anteriores, sobre todo porque, unos años después, en las Cortes de Burgos de 1453, exponían las mismas quejas: "otrosi suplicamos asimismo a vuestra alteza que le plaga de mandar ejecutar por los vuestros pedidos e monedas e otros pechos e derechos que a vuestra alteza son devidos de los annos pasados, en las cibdades e villas e lugares del regno de Galicia enbiándolos mandar con grandes fuerças e premios e firmezas e penas que los paguen". ${ }^{14}$

Ahora bien, es en este año de 1442, cuando tenemos constancia por primera vez del reparto del pedido en el reino de Galicia y conocemos sus valores. Nos consta, por otra parte, que en cada uno de los años 1442 y 1443, se efectuaron dos repartos de pedido para el reino de Galicia y las cuatro sacadas de Asturias de Oviedo, lo que nos hace suponer que fuese éste uno de los mecanismos adoptados para amortizar la deuda pendiente de años anteriores.

Tabla 1.- Primer pedido. Reino de Galicia (1442) ${ }^{15}$

\begin{tabular}{l|rrr}
\hline Partido fiscal & Cuantía $($ mrs $)$ & Cuantía $($ rls $)$ & \% \\
\hline Arzobispado de Santiago y obispado de Tuy & 1.505 .650 & 188.206 & 42,04 \\
Obispado de Orense & 1.021 .050 & 127.631 & 28,51 \\
Obispado de Lugo & 529.160 & 66.145 & 14,77 \\
Obispado de Mondoñedo & 525.220 & 65.652 & 14,66 \\
\hline Total: & $\mathbf{3 . 5 8 1 . 0 8 0}$ & $\mathbf{4 4 7 . 6 3 5}$ & $\mathbf{1 0 0}$ \\
\hline
\end{tabular}

12 OLIVERA SERRANO, C.: "Las Cortes de Castilla y el poder real (1431-1444)" En la España Medieval, $\mathrm{n}^{\circ} 11$ (1988), p. 258, no 87 y del mismo autor "El pedido de 1455..." op cit, pp. 363-374: Del total asignado al reino de Galicia en las Cortes de Valladolid de 1440, 1.790 .590 mrs., 752.855 mrs. correspondían al arzobispado de Santiago con Tuy, 510.000 mrs. al obispado de Orense, 264.580 mrs. al de Lugo y 262.610 al de Mondoñedo. Al respecto véase AGS, EMR, leg 2, s.f.

13 OLIVERA SERRANO, C.: "La ausencia de Galicia en las Cortes..."... op cit, p. 318 y Cortes de los antiguos Reinos de León y Castilla, T. III, p. 404 en FERNÁNDEZ VEGA, L.: "Las juntas del reino de Galicia...”op cit, p. 75

14 Cortes de los antiguos Reinos... op cit, T. III, p. 656 en FERNÁNDEZ VEGA, L.: "Las juntas del reino de Galicia...", op cit, p. 76.

15 AGS, EMR, leg 2 fol 415r-417v. 
Los valores correspondientes al segundo pedido repartido en 1442 son idénticos a los que se exponen en la tabla, de manera que el total asignado para el reino de Galicia este año ascendería a 7.162.160 mrs. Un año después, en 1443, se efectuaban dos repartos de pedido, seguramente iguales, aunque únicamente conocemos las cuantías asignadas al segundo de ellos, similares a las repartidas en $1442 .{ }^{16}$

En 1444, la población gallega contribuía con una tercera parte del importe global del pedido que las Cortes habían aprobado para todo el reino de Galicia. Las cuantías recaudadas en los cuatro partidos fiscales gallegos sumaron éste año un total de 1.193.664 mrs., lo que venía a suponer exactamente la tercera parte del pedido con el que el reino de Galicia debía de haber contribuido los años anteriores. El reparto porcentual relativo a la contribución de cada partido fiscal es también similar a la que se observa para los años 1442 y 1443:

Tabla 2.- Tercio del pedido. Reino de Galicia (1444) ${ }^{17}$

\begin{tabular}{l|rrr}
\hline Partido fiscal & Cuantía (mrs) & Cuantía $($ rls $)$ & \% \\
\hline Arzobispado de Santiago y obispado de Tuy & 501.895 & 62.736 & 42 \\
Obispado de Orense & 340.168 & 42.521 & 28,4 \\
Obispado de Lugo & 176.522 & 22.065 & 14,78 \\
Obispado de Mondoñedo & 175.079 & 21.884 & 14,66 \\
\hline Total: & $\mathbf{1 . 1 9 3 . 6 6 4}$ & $\mathbf{1 4 9 . 2 0 8}$ & $\mathbf{1 0 0}$ \\
\hline
\end{tabular}

Una vez más, en 1445, se efectuaban dos repartos de pedido, aunque únicamente conocemos los valores del segundo, de manera que no resulta posible estimar la cuantía global del pedido repartido este año en Galicia.

Tabla 3.- Segundo pedido. Reino de Galicia (1445) 18

\begin{tabular}{l|rrr}
\hline Partido fiscal & Cuantía $(\boldsymbol{m r s})$ & Cuantía $(\boldsymbol{r l s})$ & $\boldsymbol{\%}$ \\
\hline Arzobispado de Santiago y obispado de Tuy & 1.984 .730 & 248.091 & 42 \\
Obispado de Orense & 1.347 .734 & 168.466 & 28,5 \\
Obispado de Lugo & 698.486 & 87.310 & 14,78 \\
Obispado de Mondoñedo & 693.291 & 86.661 & 14,67 \\
\hline Total: & $\mathbf{4 . 7 2 4 . 2 9 1}$ & $\mathbf{5 9 0 . 5 3 6}$ & $\mathbf{1 0 0}$ \\
\hline
\end{tabular}

16 AGS, EMR, leg 2, fol 442.

17 AGS, EMR, leg 2, fol 262.

18 AGS, EMR, leg 2, fol 462. 
Si consideramos el primer reparto de pedido de cuantía similar a la del segundo, el valor global del pedido habría alcanzado los $9.448 .482 \mathrm{mrs}$. , una cantidad que resulta excesiva, teniendo en cuenta los valores de los años anteriores. Según los datos proporcionados por C. Olivera Serrano, en 1445, los contadores mayores habían estimado en 47.000.000 de maravedíes la recaudación del pedido de toda la Corona de Castilla, de los cuales 3.000.000 de maravedíes correspondían a Galicia, lo que representaba exactamente el 6,3\% del total. ${ }^{19}$ Esta información contrasta radicalmente con los valores que la documentación proporciona para el pedido de 1445, ya que sólo el segundo reparto efectuado este año, superaba ampliamente los tres millones de maravedíes, sumando un total de $4.724 .241 \mathrm{mrs}$. En cualquier caso, es muy posible que, en 1445, se hubiesen asignado al reino de Galicia unas cuantías de maravedíes muy superiores a lo que era habitual, como un intento más de amortizar la deuda que el reino de Galicia tenía pendiente de los años anteriores.

Los últimos datos relativos al pedido del reino de Galicia durante el reinado de Juan II, son los que se refieren a los años 1447 y 1448. En 1447, se repartieron dos pedidos de diferente cuantía, sumando un total de $4.470 .889 \mathrm{mrs}$.

Tabla 4.- Pedido. Reino de Galicia (1447) $\mathbf{2 0}^{\mathbf{2}}$

\begin{tabular}{|c|c|c|c|c|c|c|}
\hline \multirow[t]{2}{*}{ Partido fiscal } & \multicolumn{2}{|c|}{ Primer pedido } & \multicolumn{2}{|c|}{ Segundo pedido } & \multicolumn{2}{|c|}{ Total } \\
\hline & Mrs & RIs & Mrs & Rls & Mrs & RIs \\
\hline $\begin{array}{l}\text { Arzobispado de Santiago } \\
\text { y obispado de Tuy }\end{array}$ & 750.095 & 93.731 & 1.126 .507 & 140.813 & 1.876 .602 & 234.575 \\
\hline Obispado de Orense & 510.525 & 63.815 & 765.787 & 95.723 & 1.276 .312 & 159.539 \\
\hline Obispado de Lugo & 264.580 & 33.072 & 396.870 & 49.608 & 661.450 & 82.681 \\
\hline Obispado de Mondoñedo & 262.610 & 32.826 & 393.915 & 49.239 & 656.525 & 82.065 \\
\hline Total: & 1.787 .810 & 223.476 & 2.683 .079 & 335.384 & 4.470 .889 & 558.861 \\
\hline
\end{tabular}

Una vez más, parece que el hecho de que se llevaran a cabo dos repartos de pedidos anuales fuese la estrategia adoptada por los procuradores de Cortes para amortizar la deuda que el reino de Galicia tenía contraída de años pasados. Contribuye a apoyar nuestra hipótesis el hecho de que no volvamos a tener constancia de este doble reparto en años posteriores. Y por otra parte, nos consta que en el reparto del pedido de 1457, ya bajo el reinado de Enrique IV, se asignarán a cada partido fiscal unas cuantías semejantes a las repartidas en un solo pedido de

19 OLIVERA SERRANO, C.: "La ausencia de Galicia en las Cortes...", op cit, p. 318.

20 AGS, EMR, leg 2, s. f. 
$1442 .{ }^{21}$ Un año después, en 1448, el pedido alcanzaba los mismos valores que el segundo reparto efectuado en 1447, unos 2.683 .079 mrs.

Tabla 5.- Pedido. Reino de Galicia (1448) ${ }^{22}$

\begin{tabular}{l|rrr}
\hline Partido fiscal & Cuantía $($ mrs $)$ & Cuantía $($ rls $)$ & \% \\
\hline Arzobispado de Santiago y obispado de Tuy & 1.126 .507 & 140.813 & 41,98 \\
Obispado de Orense & 765.787 & 95.723 & 28,54 \\
Obispado de Lugo & 396.870 & 49.608 & 14,79 \\
Obispado de Mondoñedo & 393.915 & 49.239 & 14,68 \\
\hline Total & $\mathbf{2 . 6 8 3 . 0 7 9}$ & $\mathbf{3 3 5 . 3 8 4}$ & $\mathbf{1 0 0}$ \\
\hline
\end{tabular}

De nuevo, en 1451, los procuradores exponían al rey la resistencia que el reino de Galicia y Asturias habían mostrado al pago de pedidos reales en los años pasados, alegando que apenas habían pagado, y cuando lo habían hecho, la cantidad había sido tan exigua que ni siquiera había llegado para cubrir los gastos derivados de la recaudación. Al mismo tiempo, la deuda acumulada de años anteriores dificultaba en gran medida el pago de los pedidos que se estaban repartiendo durante los últimos años del reinado de Juan II. Precisamente este año de 1451, los procuradores de Cortes señalaban que la mayor dificultad con la que contaba el pago de pedidos consistía en el amontonamiento de deudas relativas a los años anteriores "las mayores dificultades que hay en se cobrar los dichos pedidos es por la gran suma e quantía que a cada uno cabe a pagar, segund la grand carga a que de los dichos annos pasados tienen por no haber pagado" 23

Sabemos, por otra parte, que este mismo año, el arzobispo de Santiago trató de saldar las deudas que el reino de Galicia tenía pendientes con la Hacienda Regia. Para ello, solicitaba al rey la fijación de una cantidad que pagaría el arzobispado, señalando que el valor adeudado por encima de dicha cantidad, debería ser condonado. Al parecer, la estrategia planteada por el prelado compostelano no funcionó, pues en las Cortes de Burgos de 1453, los procuradores exigían de nuevo al rey que el reino de Galicia pagase las deudas de años anteriores. ${ }^{24}$

${ }^{21}$ Sobre el pedido repartido en 1457, véase mi tesis doctoral RUBIO MARTÍNEZ, A.: Hacienda y gobierno de los Reyes Católicos en Galicia, Tesis doctoral inédita, Madrid, Universidad Complutense, 2007, pp. 170-172 y OLIVERA SERRANO, C.: "El pedido de 1455...” op cit, pp. 363-374.

22 AGS, EMR, leg 2, s. f.

${ }^{23}$ Cortes de los antiguos reinos...T. III, p. 605 en FERNÁNDEZ VEGA, L.: "Las juntas del reino de Galcia..." op cit, p. 75

${ }^{24}$ FERNÁNDEZ VEGA, L.: "Las juntas del reino de Galicia...", op cit, p. 76 
En líneas generales podemos afirmar que, la oposición que presenta el reino de Galicia al pago de servicios extraordinarios durante buena parte del siglo XV, se debió fundamentalmente a la falta de representación del reino en Cortes, aunque el origen del problema parece muy anterior y en él habrían tenido que ver una serie de factores, entre los que destacan los privilegios y exenciones fiscales que los reyes habían concedido a diversas villas y lugares de la tierra de Santiago. Así por ejemplo, sabemos que buena parte de los monasterios del reino de Galicia eran titulares de privilegios reales que les eximían del pago de pedidos y monedas. ${ }^{25}$ Pero por otra parte, conviene advertir que además de la tierra privilegiada, el arzobispado de Santiago comprendía también una proporción menor de tierra llana o realenga, obligada al pago de impuestos directos. Esta tierra realenga o reguenga, junto al resto de lugares de condición realenga estaba obligada a contribuir en el pago de pedidos o servicios extraordinarios.

Ahora bien, al margen de los privilegios y exenciones fiscales de las que era titular la denominada tierra privilegiada del arzobispado de Santiago, o las distintas instituciones eclesiásticas del reino, existieron otros motivos de peso que sin lugar a dudas, contribuyeron a fomentar la oposición del reino al pago de servicios extraordinarios. Nos estamos refiriendo a la concesión, por parte del monarca, de la mitad de las monedas y servicios extraordinarios de la tierra de Santiago al prelado compostelano.

Las primeras menciones relativas a la concesión de servicios extraordinarios que los monarcas otorgaron a la tierra de Santiago datan de 1286. El 2 de octubre de 1286, Sancho IV ordenaba a los recaudadores del servicio del reino de Galicia, entregar al arzobispo electo de Santiago, don fray Rodrigo, la mitad de los servicios que le habían sido concedidos por las Cortes de Sevilla. Cuatro años después, en 1290, Sancho IV concedía al arzobispo de Santiago, don fray Rodrigo, 20.000 mrs. en cada uno de los siete servicios que quedaban por recaudar de los diez que habían sido concedidos en Villabuena. ${ }^{26}$

Pero sin duda, el privilegio más conocido, relativo a la concesión de pedidos y monedas al arzobispo de Santiago, es el otorgado por el rey Fernando IV en 1304. El 4 de mayo de este año, Fernando IV concedía al prelado compostelano la mitad de las monedas y servicios extraordinarios de la tierra de Santiago, y unos años des-

25 Véase SÁNCHEZ BELDA, L.: Documentos reales de la Edad Media referentes a Galicia: catálogo de los conservados en la sección de clero del Archivo Histórico Nacional, Madrid, 1953.

26 NIETO SORIA, J.M.: Iglesia y poder real en Castilla: el episcopado (1250-1350), Madrid, 1988, p. 134 citado por GONZÁLEZ VÁZQUEZ, M.: El arzobispo de Santiago: una instancia de poder en la Edad Media (1150-1400), La Coruña, 1996, p. 242. 
pués, en 1313, el rey Alfonso XI reiteraba esta concesión al reconocer a la Iglesia de Santiago el derecho a recaudar la mitad de los servicios y monedas de los lugares pertenecientes a su jurisdicción en los reinos de Galicia, León y Castilla. Del mismo modo, el 20 de mayo de 1317, Alfonso XI ordenaba que la mitad de los servicios que le habían sido concedidos en las Cortes de Carrión se recaudasen en la tierra de Santiago para su Iglesia. ${ }^{27}$

Sin embargo, la Iglesia de Santiago no sería la única agraciada con este tipo de mercedes reales, sino que la propia ciudad de Santiago también se vio beneficiada por los privilegios de estos monarcas. Así, es bien sabido que Sancho IV había hecho merced a los vecinos y labradores de la ciudad de Santiago de todos los servicios y pedidos que se le debiesen o que se repartiesen en el reino de Galicia, un privilegio que sería confirmada por los reyes Fernando IV y Alfonso XI. ${ }^{28}$

No cabe duda de que la concesión de servicios y monedas a diversas instituciones, laicas o eclesiásticas, del reino de Galicia contribuyó a incrementar la negativa de la población gallega al pago de estos tributos a la Hacienda Real. Pero por otra parte, es preciso destacar que la dificultad para recaudar los pedidos reales en el reino de Galicia se incrementaba ante la exención generalizada del pago de monedas que existía para todo el reino. En 1451, los procuradores de Cortes insistían en la dificultad para recaudar los pedidos en el reino de Galicia por este motivo: "la gran cabeza que tienen, porque lo mesmo que montava el pedido e moneda se echó todo en pedido" 29

En relación con la exención del reino de Galicia al pago de monedas, únicamente tenemos noticia del privilegio ya mencionado por el que Fernando IV hacía merced al prelado compostelano en 1304, de la mitad de las monedas y servicios extraordinarios de la tierra de Santiago, y la reafirmación del rey Alfonso XI en este sentido, al confirmar a la Iglesia de Santiago, en 1313, la mitad de los pechos, servicios y monedas que había recibido de los monarcas anteriores, a recaudar en sus dominios jurisdiccionales de los reinos de Galicia, León y Castilla. ${ }^{30}$

27 Sobre cada una de estas concesiones veáse GONZÁLEZ BALASCH, M. T.: El Tumbo B de la catedral de Santiago de Compostela, Santiago, 2004 (Doc. 220, p. 420, doc. 150, p. 309, doc. 217, p. 416 , doc. 219 , p. 419 , doc. 121 , p. 262 y doc.40, p. 140).

${ }^{28}$ LÓPEZ FERREIRO, A.: Fueros municipales de Santiago y su tierra, Santiago, 1895-96, Repr. 1975 , p. 422.

29 Cortes de los antiguos reinos...T. III, p. 606 en FERNÁNDEZ VEGA, L.: "Las juntas del reino...”op cit, p. 76

30 GONZÁLEZ BALASCH, M. T.: El Tumbo B de la catedral de Santiago...op cit, doc. 217, p. 416 y doc. 121, p. 262. 
Los privilegios mencionados nos permiten afirmar que, al menos desde principios del siglo XIV, la Iglesia de Santiago era titular de la mitad de las monedas con las que los habitantes de la tierra de Santiago debían contribuir a la Hacienda Regia. Es posible que estos privilegios, otorgados en un primer momento a la Iglesia de Santiago, con el tiempo se hubiesen ido extendiendo a todo el reino de Galicia. A pesar de no conocer ningún privilegio real que, con carácter general, eximiera del pago de monedas a todo el reino, todo parece indicar que, en algún momento del siglo XIV, los monarcas habrían generalizado la exención del pago de monedas a todo el reino de Galicia, pues los repartos de monedas del siglo XV, excluyen por completo a dicho reino. ${ }^{31}$

La Iglesia y la ciudad de Santiago también recibieron una parte del producto de la moneda forera con la que la población gallega debía contribuir a la Hacienda Regia en reconocimiento del señorío real. Según se constata en la documentación, desde principios del siglo XIV, la Iglesia de Santiago era titular de la mitad del producto de la moneda forera que se pagaba en la tierra de Santiago. Sólo así se explica, que el 28 de junio de 1313, Alfonso XI concediera al arzobispo de Santiago $20.000 \mathrm{mrs}$. en la mitad de la moneda forera perteneciente al rey en las sacadas del reino de Galicia. ${ }^{32}$ Nos consta por otra parte que la ciudad de Santiago de Compostela también había recibido ciertas exenciones en el pago de moneda forera. Así, sabemos que el rey Sancho IV había condonado a los burgueses de Compostela cuatrocientas monedas del valor global del encabezamiento de la moneda forera y Enrique III confirmaba este privilegio a la ciudad de Santiago en 1399:

“.. por fazer bien e merced a la dha ciudad que les quitaron para siempre jamás cuatrocientas monedas, tanbién de monedas foreras, como de servicios que le oviesen a dar los concejos e los otros de mis Reynos..." 33

No obstante, a pesar de las concesiones mencionadas, durante los siglos XIV y $\mathrm{XV}$, el pago de moneda forera en la tierra de Santiago se extendía no sólo a la tierra llana, sino también a la tierra privilegiada, aunque esta última estuviera en muchos casos exenta del pago de dichos tributos. Buena prueba de ello es la sentencia que en 1376, declaraba a la tierra de Trasancos y a las feligresías, collaciones y lugares a ella pertenecientes, exentos de pagar monedas al rey, salvo unas

31 Los repartos generales de monedas para toda la Corona de Castilla en los años 1429, 1430 y 1431, excluyen por completo al reino de Galicia. Al respecto veáse AGS, EMR, leg 1, fols 217-218, 225-226 y 235-236.

32 GONZÁleZ BALASCH, M.T.: El Tumbo B de la catedral de Santiago...op cit.., doc. 17, p. 95

33 LÓPEZ FERREIRO, A.: Fueros Municipales....op cit, p. 425 
cáñamas en reconocimiento del señorío real. La propia sentencia declaraba a los vecinos y moradores de la tierra de Trasancos hijosdalgo notorios, exentos del pago de monedas, pechos, pedidos o cualquier otro tributo de carácter extraordinario, a excepción de la moneda forera. El 16 de agosto de 1413, Juan II confirmaba este privilegio a los vecinos y moradores de la tierra de Trasancos, y unos años después, en 1420, el monarca confirmaba una sentencia otorgada en 1373 al monasterio y coto de San Salvador de Pedroso, en la tierra de Trasancos, que eximía a sus habitantes del pago de monedas por cabezas y otros pechos o tributos reales con excepción de las dos cáñamas de monedas que se pagaban cada siete años en reconocimiento del señorío real. Los Reyes Católicos confirmaban estos privilegios el 20 de marzo de $1484 .{ }^{34}$

La concesión de exenciones y franquezas de este tipo, especialmente en la tierra de Santiago, contribuyó en cierto modo a generalizar la oposición del reino de Galicia al pago de pedidos y servicios extraordinarios, pero lo cierto es que todo el reino de Galicia estaba obligado a contribuir con el pago de estos tributos al fisco regio, de manera que, en la tierra de Santiago, el pago de pedidos se extendía no sólo a la tierra llana sino también a la tierra privilegiada. ${ }^{35}$

\section{LA RECAUDACIÓN DE PEDIDOS REALES EN TIEMPOS DE ENRIQUE IV}

De acuerdo con lo señalado en el apartado anterior, es posible afirmar que durante buena parte del siglo XV, el reino de Galicia se resistió al pago de servicios extraordinarios otorgados por las Cortes del reino, lo que indudablemente ocasionó notables pérdidas para la Hacienda Regia. Esta resistencia al pago de servicios extraordinarios se evidencia todavía a principios de los años sesenta, si bien es cierto que desde los últimos años del reinado de Juan II, el reino de Galicia está presente en los repartimientos de servicios. Nos hemos referido también al motivo fun-

\footnotetext{
34 AGS, RGS, Tarazona, 20 de marzo de 1484, fols 1 y 2.

35 AGS, EMR, leg 1, fol 556 y leg 17, fols 89 y 121: Los repartos de pedidos del reino de Galicia de los años 1457 y 1462 nos permiten comprobar que, en el pago de pedidos de la tierra de Santiago contribuía no sólo la tierra llana o realenga, sino también la tierra privilegiada. Las cartas de receptoría relativas a cada uno de estos años mencionan como contribuyentes a la ciudad de Santiago con la sacada de Posmarcos, las villas de Noya y Padrón, la sacada de Entrambos puertos, Pontevedra, Vigo, Redondela, la sacada de Salas, Caldas de Reis, la sacada de Deza, la villa de Melide, la sacada de Trastámara, Finisterre, la villa de Muros, y otras villas, lugares, tierras llanas, cotos, feligresías y encomiendas de las sacadas.
} 
damental que la población gallega argumentó, una y otra vez, para justificar la oposición del reino de Galicia al pago de servicios extraordinarios: la falta de representación de los procuradores gallegos en las Cortes del reino. Sobre esta cuestión, contamos con un testimonio del concejo de Orense, que en 1465 respondía al interrogatorio propuesto por la corte de Enrique IV en los siguientes términos:

"que por quanto el dicho Regno de Gallizia es regnado sobre sy de vuestra alte$z a$, que los procuradores del dicho vuestro Regno deverían ser llamados para las cosas semejantes, según que antes lo eran, e por ellos ser sabidores de las dichas necesidades e menesteres de Vuestra Alteza, esto mismo para que ellos dixesen a Vuestra Alteza e vos informasen de las cosas complideras a vuestro real servicio e al bien e pro común, gobernación e regimiento del dicho vuestro regno, et quando fueren llamados e sabidas vuestras necesidades e menesteres, ellos como buenos e leales vasallos vuestros e de vuestra señoría no fueran menos obedientes a vos faser servicio e otorgar a Vuestra Real Señoría todo aquello que a ellos posible fuese de pagar según sus quantidades e faziendas los pudiesen pagar, para lo qual disen que pues non fueron llamados nin por ellos otorgados que por esta rason no son ni seran obligados de pagar lo que los otros procuradores de los otros vuestros regnos que para ello fueron llamados lançaron e repartieron en el dicho vuestro regno... "36

La respuesta del concejo de Orense al monarca, pone de manifiesto que los gallegos recurrieron al mejor de los argumentos para escapar a la contribución del pedido, aunque existieran otros no menos importantes, ya mencionados. Sabemos por otra parte, que todavía a principios del siglo XVI, la población gallega continuaba refiriéndose a la falta de representación de los procuradores gallegos en las Cortes del reino, como motivo fundamental para justificar la oposición al pago de servicios extraordinarios. No obstante y a pesar de las dificultades que planteó el pago de servicios extraordinarios en el reino de Galicia durante el reinado de Enrique IV, tenemos constancia de que el reino contribuyó en los repartos de pedido de los años 1457 y $1462 .{ }^{37}$

\subsection{El pedido de 1457}

Al comenzar el reinado de Enrique IV, concretamente en los años 1455 y 1456, se llevaba a cabo el repartimiento de un nuevo servicio, en el que el reino de Gali-

36 Publicado por GARCÍA ORO, J.: Galicia en la Baja Edad Media, Santiago, 1977, pp 245-248.

37 AGS, EMR, leg 1, fols 556-569 (1457) y leg 16, fols 137 y 139 y leg 17, fols 2, 89-92, 121129 (1462). 
cia no contribuyó, teniendo en cuenta que este año se aplicaba un descuento a los arrendadores mayores de 4.000.000 de maravedíes sobre un total de 87.541.000 mrs. por la "quiebra de Galicia", lo que venía a suponer algo menos de un cinco por ciento del total. ${ }^{38}$

Sin embargo, dos años después, en 1457, se efectuaba un nuevo repartimiento de servicio extraordinario en el que si tenemos documentada la contribución de los distintos partidos fiscales gallegos. ${ }^{39}$ Efectivamente, el estudio de la documentación hacendística pone de manifiesto que la contribución de cada uno de los partidos fiscales gallegos en el reparto del pedido de 1457 se efectuó por regiones o comarcas fiscales. ${ }^{40}$ Y por otra parte, la documentación procedente de la Escribanía Mayor de Rentas nos permite conocer las cuantías asignadas a cada partido fiscal, con detalle de la cantidad con la que debía contribuir cada una de las unidades fiscales. Así, sabemos que la recaudación del pedido en el arzobispado de Santiago generó unos ingresos de 1.507.320 mrs. La Iglesia de Santiago era titular de 39 escusados de merced de juro de heredad en el pedido que se repartiese en el arzobispado, lo que equivalía a unos $2.730 \mathrm{mrs}$. La mayor de las regiones fiscales del arzobispado de Santiago por su nivel de contribución era la que encabezaba la ciudad de Santiago con la sacada de Posmarcos, en la que quedaban incluidas las villas de Noya y Padrón, la sacada de entreambos puertos con Pontevedra, Vigo y Redondela, la sacada de Salas con Caldas de Reis, la sacada de Deza y la villa de Melide, la sacada de Trastámara, Finisterre y la villa de Muros y las otras villas, lugares y tierras llanas, cotos, feligresías y encomiendas de las sacadas. La segunda de estas regiones fiscales era la que comprendía las tierras llanas, cotos y encomiendas que Fernán Pérez de Andrade poseía en la sacada de Trastámara contra Ortigueira, así como todas aquellas tierras llanas, encomiendas y otros lugares, pertenecientes a cualquier otra persona en dicha sacada. Le seguían en importancia el concejo de La Coruña sin los cotos de la ciudad, Villalba de Montenegro con su alfoz, la villa de Betanzos con su alfoz etc...41

En el obispado de Orense, el valor del pedido de 1457 alcanzó una cantidad algo inferior a la recaudada en el arzobispado de Santiago: $989.950 \mathrm{mrs}$. Entre las regiones fiscales de mayor importancia de este partido por la cuantía de pedido asignada destacaba en primer lugar el concejo de la ciudad con los cotos del obispo y el

38 LADERO QUESADA, M. A.: La Hacienda Real de Castilla ...op cit, p. 208.

39 Sobre el repartimiento del pedido de 1457 véase OLIVERA SERRANO, C.: "El pedido de 1455..." op cit, pp. 363-374.

40 AGS, EMR, leg 1, fol. 556-570v.

${ }^{41}$ AGS, EMR, leg 1, fol 556-558. 
coto de Cebollido. Se asignaba también una cuantía de pedido considerable al concejo de Castro Caldelas y su tierra, el coto de San Clodio, San Payo, Carvajal, Castro de Boadas, San Vicente, Acevedo y Reigada, perteneciente a la jurisdicción del monasterio de Santa María de Carracedo con tierra de Manzaneda, sin la encomienda de San Vicente, con el coto de Cobin, la Iglesia y encomienda de Montarratín, la encomienda de Puerto, Castro de Valdeorras con su tierra, tierra de Quiroga de Cabo con el castillo de Os Novais, el coto de Santa Cristina, la tierra de Caldas sin la encomienda de Sobrada. Le seguían en importancia otras regiones como la que comprendía los lugares, cotos y feligresías de Limia con el coto de Riocaldo, sin la villa de Monterrey y su alfoz. ${ }^{42}$

Las cantidades recaudadas en concepto de pedido en el obispado de Lugo alcanzaron un total de 529.160 mrs., una cantidad que se repartía entre los concejos, cotos y lugares que componían las pequeñas regiones fiscales de este partido. La distribución del pedido por localidades nos permite comprobar que la mayor proporción fue asignada a la ciudad de Lugo con sus cotos, a la que correspondieron 99.240 mrs., un $18,75 \%$ del total. En proporciones inferiores, pero de importancia notable, se encabezaban el concejo de Burón y su alfoz (14.290), la villa de Monforte (15.300), la puebla de Brollón (11.240), Monterroso (24.380), Chantada y su alfoz (28.590) y la tierra de Ulloa y Repostería (32.800). ${ }^{43}$

Por último, en el obispado de Mondoñedo, el total del pedido sumó este año 525.220 mrs., una cantidad muy aproximada a la asignada al obispado de Lugo, que debía ser repartida entre un número inferior de unidades fiscales, debiendo contribuir cada una de ellas, con una cuantía de maravedíes muy superior a la que debían satisfacer las poblaciones incluidas en el reparto del pedido de Lugo. En este caso sabemos que la mayor proporción del reparto recayó sobre la ciudad de Mondoñedo con los concejos, moradores y pobladores de la tierra llana, a la que correspondieron 199.690 mrs., lo que venía a suponer el 38\% del total. En menor proporción se situaba la villa de Vivero con sus valles y términos, con $127.840 \mathrm{mrs}$. (24,3\%), Santa Marta y su alfoz, a la que correspondían $58.030 \mathrm{mrs}$. (11,04\%), o la villa de Ribadeo con 42.040 mrs (8\%). ${ }^{44}$ Finalmente, las cuantías repartidas por el pedido de 1457 a los cuatro partidos fiscales gallegos sumaron un total de $3.551 .650 \mathrm{mrs}$, una cifra muy aproximada a los $4.000 .000 \mathrm{mrs}$. asignados al reino de Galicia en concepto de pedido los años de 1455 y $1456 .{ }^{45}$

42 AGS, EMR, leg 1, fol 559-563

43 AGS, EMR, leg 1, fol 564-569.

44 Ibidem.

45 LADERO QUESADA, M.A.: La Hacienda Real de Castilla...op cit, p. 208. 
Tabla 6.-Pedido. Reino de Galicia (1457)

\begin{tabular}{lrrr}
\hline Partido fiscal & Mrs & $\boldsymbol{R l s}$ & $\boldsymbol{\%}$ \\
\hline Santiago y Tuy & 1.507 .320 & 94.207 & 42,43 \\
Orense & 989.950 & 61.871 & 27,87 \\
Lugo & 529.160 & 33.072 & 14,89 \\
Mondoñedo & 525.220 & 32.826 & 14,78 \\
\hline Total & $\mathbf{3 . 5 5 1 . 6 5 0}$ & $\mathbf{2 2 1 . 9 7 8}$ & $\mathbf{1 0 0}$ \\
\hline
\end{tabular}

\subsection{El pedido de 1462 .}

De nuevo en 1462, el reino de Galicia se oponía al pago de tributos extraordinarios, situación que se constata en las Cortes de este año, que propusieron el envío de un corregidor y dos contadores mayores al reino de Galicia, tratando de solucionar el problema. ${ }^{46}$ No cabe duda de que el envío de estos oficiales reales al reino de Galicia, debió tener los buenos resultados, pues a partir de este momento volvemos a tener noticia del reparto efectivo del servicio extraordinario en el reino de Galicia.

Una carta de pedido fechada en 1462 pone de manifiesto como Enrique IV había solicitado a las principales villas y ciudades del reino el envío de sus procuradores a la corte, donde se reunirían con los miembros del consejo para acordar el reparto del pedido de los años 1462 y 1463. En aquel momento formaban parte del consejo miembros de especial relevancia y afectos a la política del monarca: el arzobispo de Toledo y primado de las Españas, Alfonso Carrillo, el marqués de Villena y mayordomo mayor del rey, don Juan Pacheco, y el contador mayor, Diego Arias Dávila. En esta ocasión, el monarca solicitaba la aprobación de los servicios extraordinarios aludiendo a la gran necesidad de recursos para la defensa y afianzamiento de sus reinos y para la lucha de los moros enemigos:

“.. Y como a mi cumplía mucho defenderlos y afianzarlos y hacer guerra y mal y daño a los dichos moros enemigos de nuestra santa fé lo cual no se podría ni puede hacer sin que los dichos mis regnos me sirviesen con algunas cuantías de maravedies" 47

Una vez aprobado el pago del servicio por los procuradores de cortes se procedía a fijar los plazos de entrega. Así, según se especifica en la carta de pedi-

46 GARCÍA ORO, J.: Galicia en los s. XIV y XV. vol I...op cit, p. 303.

47 AGS, EMR, leg 17, fol 2: Carta de pedido. Galicia y Asturias de Oviedo. "Nota por do se hicieron las cartas del pedido que se repartió para el arzobispado de Santiago con el obispado de Tuy y de los obispados de Lugo, Orense, Mondoñedo y Asturias de Oviedo deste año de 1462”. 
do, una primera parte, correspondiente al año 1462, debería ser satisfecha a final de los meses de agosto y diciembre, mientras que la otra mitad, correspondiente al año 1463, debería ser entregada en los meses de marzo y junio de dicho año.

Indudablemente, el reparto del servicio extraordinario de 1462 debió suponer un gran esfuerzo económico para la población gallega que al mismo tiempo tenía que hacer frente al pago de los impuestos reales ordinarios y a un sinfín de derechos y exigencias de carácter señorial. A pesar de que las fuentes disponibles no permiten calcular la presión fiscal a la que se vio sometida la población gallega durante estos años, contamos con algunos testimonios documentales que nos informan acerca de las dificultades a las que se tuvo que enfrentar la población gallega para hacer efectivo el pago del pedido.

Tabla 7.- Reino de Galicia. Pedidos (1462-1463). ${ }^{48}$

\begin{tabular}{l|rrrrr}
\hline Partido fiscal & $\mathbf{1 4 6 2}$ & $\mathbf{1 4 6 3}$ & Total $(\boldsymbol{m r s})$ & Total $(\boldsymbol{r l s})$ & $\boldsymbol{\%}$ \\
\hline Arzobispado de Santiago & 1.690 .888 & 1.690 .888 & 3.381 .776 & 211.361 & 42,10 \\
y obispado de Tuy & & & & & \\
Orense & 1.148 .657 & 1.128 .908 & $2.277 .565^{49}$ & 142.347 & 34,55 \\
Lugo & 595.273 & 595.273 & 1.190 .546 & 74.409 & 14,82 \\
Mondoñedo & 590.868 & 590.868 & 1.181 .736 & 73.858 & 14,71 \\
\hline Total & $\mathbf{4 . 0 2 5 . 6 8 6}$ & $\mathbf{4 . 0 0 5 . 9 3 7}$ & $\mathbf{8 . 0 3 1 . 6 2 3}$ & $\mathbf{5 0 1 . 9 7 6}$ & $\mathbf{1 0 0}$ \\
\hline
\end{tabular}

48 Tabla elaborada según los datos que proporciona la EMR. Para el arzobispado de Santiago Véase leg 17, fols 89, 121 y 122, Orense: leg 16, fol 139 y leg 17 fols 91, 126, 127 y 128, Lugo: leg 17, fols 90, 123, 124 y 125, Mondoñedo: leg 16, fol 137 y leg 17, fols 92 y 129.

49 En el reparto del pedido de Orense llama la atención como las cifras de los dos años no son exactamente iguales como correspondería y ocurre en los otros partidos fiscales. El reparto del pedido por unidades fiscales, pone de manifiesto que, paradójicamente, las cuantías asignadas en el reparto de 1463 son ligeramente superiores a las repartidas en 1462, con excepción de la villa y tierra de Aguiar, cuyas cifras revelan una gran diferencia, pasando de $40.871 \mathrm{mrs}$. en 1462 a $11.119 \mathrm{mrs}$. en 1463. Esta diferencia que se registra en la documentación en las cuantías del pedido de los años 1462 y 1463 , podría deberse a la percepción de una parte del pedido por el prelado compostelano, teniendo en cuenta que unos años antes, los prelados compostelanos habían sido titulares de la jurisdicción de la villa y tierra de Aguiar con todas las rentas y derechos derivados del ejercicio de la misma, incluidas las alcabalas, que el arzobispo de Santiago continuará percibiendo durante todo el reinado de Enrique IV, a pesar de haber traspasado en 1458 la jurisdicción de la villa y tierra de Aguiar al conde de Benavente en calidad de "feudo perpetuo".

La percepción de las alcabalas de la tierra de Aguiar por parte del prelado compostelano durante los años sesenta, plantea la posibilidad de que el arzobispo percibiese una parte del pedido real mediante toma, aunque la documentación no registra ningún dato al respecto que permita asegurarlo. 


\section{EL REINADO DE LOS REYES CATÓLICOS: EL PEDIDO DE 1476 Y LA CONTRIBUCIÓN DE LA HERMANDAD}

Desde principios de los años sesenta, la negativa fiscal que durante años había caracterizado al reino de Galicia comenzaba a desaparecer, si bien, todavía en 1465 se localizan algunos focos de resistencia, tal y como se deduce de las respuestas del concejo de Orense al interrogatorio propuesto por la corte de Enrique IV. ${ }^{50}$ Por consiguiente, será preciso esperar a los primeros años del reinado de los Reyes Católicos, en los que se observan los primeros síntomas de desaparición de esta resistencia al pago de servicios extraordinarios votados en Cortes, al tiempo que desaparecían otros antiguos malos usos fiscales y se daban los primeros pasos hacia la regularización hacendística en las contribuciones ordinarias.

Las Cortes celebradas en Madrigal en 1476, cerraban un período de dificultades económicas y financieras comunes a toda la Corona de Castilla. Estas cortes eran las primeras del reinado y las últimas en votar servicios extraordinarios hasta 1500 , pues precisamente en las Cortes de Madrigal se aprobaba la constitución de la Santa Hermandad, que sustituiría los tradicionales pedidos reales votados por las Cortes del reino por la denominada contribución de la Hermandad. Pocos son los datos con los que contamos acerca del reparto del pedido de 1476 y de su distribución por provincias fiscales. Sin embargo, gracias a un manuscrito conservado en la Real Academia de la Historia nos ha sido posible conocer algunos aspectos sobre la cuantía y organización del pedido aprobado por las Cortes de Madrigal. ${ }^{51}$ Según se especifica en el mencionado manuscrito, las Cortes de 1476, aprobaron un total de 120.000.000 de maravedíes a repartir entre este año y el siguiente, una cantidad muy elevada, sin duda la mayor que las Cortes habían aprobado en los últimos años.

Pero también, el manuscrito de la Academia de la Historia permite conocer algunos detalles relativos al reparto y distribución de las cuantías recaudadas en concepto de pedido. Sabemos por ejemplo, que los procuradores de Cortes propusieron a la reina el nombramiento de un prelado como presidente, con los oidores, alcaldes y otros oficiales que fuesen necesarios, al tiempo que señalaban que el salario de estos oficiales debería ser pagado de la cuantía del pedido, siendo el prior de San Benito el encargado de pagar dichos sueldos. Nos consta también, que la reina había encargado a los procuradores de Cortes entregar al conde de Benavente cierta suma de maravedíes en enmienda de los daños que había recibido en sus

50 Véase p. XX de este trabajo.

51 RAH, manuscrito 9/1784. 
actuaciones al servicio de la monarquía, una cantidad que debería ser satisfecha con cargo a los 120 cuentos votados en Cortes.

Los procuradores de las Cortes de Madrigal insistían en la forma en que debía ser administrado el pedido de 1476. En este sentido, se establecía que los maravedíes del pedido se destinarían exclusivamente al pago de sueldos y salarios de oficiales reales, y que en ningún caso podrían dedicarse al pago de deudas a persona alguna, salvo a los grandes del reino, en cuyo caso se abonarían las deudas contraídas desde las Cortes de Toro. Por último, se determinaba que la gestión del pedido se llevaría a cabo a través de los recaudadores y recebtores nombrados por los procuradores, que obtendrían carta de recudimiento, previa entrega de las fianzas oportunas.

A pesar de ser muy pocas las noticias que tenemos sobre el reparto y distribución del pedido de 1476, sabemos que el reino de Galicia contribuyó en el pago del mismo. Así, la documentación nos informa acerca de la orden que los reyes enviaron al tesorero Fernando de Mazuelo el 11 de febrero de 1477, con el fin de que averiguara las cuantías que se debían en todo el reino de Galicia en concepto de tributos ordinarios y extraordinarios, correspondientes al período 1453-77, incluidas las deudas derivadas del pedido líquido de $1475 .{ }^{52} \mathrm{Y}$ un año después, el 4 de marzo de 1478, enviaban una nueva carta al tesorero Mazuelo, encargándole la recaudación de ciertas cuantías de maravedíes que tenían pendientes el conde de Altamira y el mariscal Pardo de Cela del pedido de 1476, por lo que se había repartido de más en sus lugares solariegos y encomiendas. ${ }^{53}$ Efectivamente, el 10 de junio de 1478, se ordenaba al mariscal Pedro Pardo de Cela pagar al contador Francisco García de Toledo y al receptor Gonzalo de Valencia, los maravedíes que le quedaban por pagar de los pedidos y monedas que correspondían a su tierra. ${ }^{54}$

\subsection{Los ingresos procedentes de la contribución de la Hermandad (1476-1498)}

El proceso de implantación de la Hermandad en el reino de Galicia se considera un fenómeno tardío, en el que tuvo una gran incidencia la oposición de buena parte de la nobleza y oligarquía gallega, que dificultó, en cierto modo, la fundación de la institución en el reino y su correcto funcionamiento en el plano fiscal. Por este motivo, la Hermandad no se establecería en el reino de Galicia hasta 1480, teniendo efectos económicos desde 1482 en adelante. En estas circunstancias, el 18 de

52 AGS, EMR, leg 23, fol. 51.

53 AGS, EMR, leg 25, fol. 47.

54 AGS, RGS, Sevilla, 10 de junio de 1478, fol. 59. 
febrero de 1480, los reyes otorgaban carta de poder a don Antonio de Paz, arcediano de Camaces y al licenciado Fernando Gómez de Tordehumos para acudir a Galicia a establecer la Hermandad:

"Don Fernando y doña Isabel por la gracia de Dios rey y reina etc.. a los concejos, corregidores, alcaldes, alguaciles, merinos, regidores, caballeros, escuderos, oficiales y omes buenos de todas las ciudades y villas y lugares así realengos como abadengos y señoríos y ordenes y behetrías... Sepades que por algunas cabsas que a ello nos mueven cumplideras a servicio de Dios y nuestro y al bien de nuestros reinos y acrecentamiento de la hermandad dellos, nos enviamos a ese dicho nuestro reino de Galicia con nuestros poderes bastantes y de la diputación general de la dicha hermandad a don Antón de Pas, arcediano de Camaces y al licenciado Fernand Gomes de Tordehumos, ambos de nuestro consejo a poner en hermandad a ese dicho nuestro reino de Galicia....." 55

Y sólo diez días después, pedían a todas las ciudades, villas y lugares del reino de Galicia que recibiesen la Hermandad y prestasen la ayuda necesaria al arcediano de Camaces y al licenciado Fernán Gómez de Tordehumos, que habían acudido al reino de Galicia a imponer la Hermandad con poderes de los reyes y de la diputación general. ${ }^{56}$

A pesar de la oposición presentada por algunos nobles y caballeros gallegos, la Hermandad se establecía en Galicia en $1480 .{ }^{57}$ Desde este momento, los reyes la dotaban de autonomía propia, aunque en la práctica tuviera la misma organización que la castellana y estuviera regida por el Consejo de la Hermandad. Así, sabemos que en 1482, los representantes de los municipios gallegos solicitaron una moderación de las cuantías con las que debían contribuir, proponiendo que los cargos de diputados, tesoreros y recaudadores de la institución fuesen ocupados por personajes gallegos, y que el representante del reino de Galicia en el Consejo de la Hermandad fuese ocupado por un gallego. El cuerpo de la Hermandad estaba formado por trescientas lanzas que deberían ser retribuidas de acuerdo a los estatutos de la Hermandad, un cuerpo que según opinaban los representantes de los municipios, debería estar formado también por caballeros gallegos. ${ }^{58}$

55 AGS, RGS, Toledo, 18 de febrero de 1480, fol 209.

56 AGS, RGS, Toledo, 28 de febrero de 1480, fol 208

57 GARCÍA ORO, J.: Galicia en los S. XIV y XV. vol I...op cit, pp.331-335.

58 Sobre todas estas cuestiones véase LÓPEZ FERREIRO, A.: Fueros Municipales...,op cit, vol. II, pp. 310-317, citado por GARCÍA ORO, J.: Galicia en los S. XIV y XV...op cit, vol I, p. 336. 
A pesar de que los reyes no atendieron directamente las peticiones de los municipios gallegos, es evidente que las exigencias de los concejos facilitaron la modificación de algunos aspectos de la Hermandad, especialmente todo lo relativo a las formas de contribución. Parece lógico, por otra parte, que la monarquía se viera obligada a aceptar algunos cambios en la forma de contribuir de los gallegos, sobre todo teniendo en cuenta las continuas quejas que los concejos gallegos hacían llegar a los reyes, ante la imposibilidad de hacer frente a tributos tan elevados.

Por consiguiente, en 1484, se producían algunos cambios importantes en la organización de la Hermandad gallega. Este año, el arcediano de Camaces, diputado general de la Hermandad, era sustituido por Álvaro de Gijón, que en lo sucesivo actuaría como receptor y tesorero de la Hermandad. La labor llevada a cabo por el nuevo receptor de la Hermandad, levantó polémica desde el primer momento, sobre todo por parte de los vecinos de La Coruña, que se quejaban continuamente de los abusos que Álvaro de Gijón estaba cometiendo en la ciudad. La solución por parte de los reyes llegaba el 28 de octubre de 1484, fecha en la que encargaban a su gobernador en el reino de Galicia, Diego López de Haro, resolver la forma en que la ciudad de La Coruña debía contribuir en la Hermandad conforme a lo establecido en años anteriores por el arcediano de Camaces. ${ }^{59}$

Sin embargo, estos no fueron los únicos problemas a los que se tuvo que enfrentar la Hermandad en el reino de Galicia. La documentación deja constancia de que durante estos años, buena parte de la población gallega se resistía a empadronar las ciudades, villas y lugares, tierras, cotos y feligresías, oponiéndose directamente al pago de la contribución de la Hermandad. Alegaban que la contribución era pecho y moneda que perjudicaba las franquezas, exenciones y títulos de hidalguía de buena parte del reino de Galicia. Contra semejantes afirmaciones, el 23 de diciembre de 1484, los Reyes Católicos declaraban que “... la dicha contribución no fue ni es pecho ni tributo ni monedas ni tal nombre se le debió ni debe poner ni llamar, salvo servicio gracioso de propia voluntad por nuestros reinos otorgado y para cierta necesidad y a tiempo cierto y limitado.." 60

Con estas palabras, los reyes ordenaban que en lo sucesivo la contribución de la Hermandad no fuese llamada "pecho ni moneda ni tributo", sino simplemente "servicio" y expresaban su intención de que el empadronamiento no perjudicase en ningún caso los privilegios y libertades de los contribuyentes. No obstante, a pesar del respeto a los privilegios y franquezas a título personal, la contribución de la Hermandad se entendía como un servicio de carácter universal, en el que deberían con-

59 AGS, RGS, Sevilla, 28 de octubre de 1484, fol 186.

60 AGS, RGS, Sevilla, 23 de diciembre de 1484, fol 78. 
tribuir todas las personas de cualquier estado o condición, incluidos los vasallos de instituciones eclesiásticas. Únicamente quedaban exentos del pago aquellos hidalgos que pudieran demostrar su condición mediante privilegio, además de aquellas villas y lugares a los que los reyes hubieran concedido alguna exención temporal por algún motivo. En este caso se encontraba la villa de Ribadeo en 1495, cuando los reyes la habían eximido del pago de los maravedíes de los peones de la Hermandad, ordenando que la cantidad que correspondiese pagar a la villa y tierra se entregase al mayordomo que el conde tuviese en la villa. ${ }^{61}$

La contribución de la Hermandad se mostraba novedosa con respecto a los repartos de tributos extraordinarios que se habían efectuado en el reino de Galicia en los años anteriores, sobre todo porque no tenía en cuenta los antiguos privilegios que eximían a determinadas instituciones eclesiásticas del pago de contribuciones directas. Pese a ello, los reyes declaraban que la contribución de la Hermandad en ningún caso perjudicaba las exenciones del estamento eclesiástico, porque los privilegios y exenciones que disfrutaban no justificaban el impago de este nuevo "servicio". Así lo expresaban los reyes el 23 de diciembre de 1484 :

“....declaramos que según el tenor y forma de las dichas leyes y ordenanzas fechas cerca de la paga de la dicha contribución, que los dichos caseros y vasallos y escusados desas dichas iglesias y monasterios y abadías y hospitales y vecinos y moradores en las tierras y señoríos dellos no se pueden ni deben escusar de pagar la dicha contribución de la dicha Hermandad y que la deben y son tenidos y obligados a la pagar, sin embargo de las dichas cartas y privilegios y exenciones que así tenedes y que aquello sin alguno dellos no ympide embargar la dicha paga de la dicha contribución de la Hermandad, ni se extiende ni extendieron a ella en manera alguna ni a los excusar de ser empadronados y que por ello no se quebrantan ni perjudican en las dichas sus exenciones" 62

Este mismo año, el procurador del reino de Galicia proponía a los reyes que el procedimiento recaudatorio de la contribución de la Hermandad se llevase a cabo mediante una tasa o encabezamiento que evitaría los posibles fraudes que habitualmente generaba el arrendamiento. ${ }^{63}$ Desconocemos la fecha exacta en la que la contribución de la Hermandad habría empezado a gestionarse mediante esta tasa o encabezamiento, pero lo que si es seguro es que al menos en 1494, el repartimien-

\footnotetext{
61 AGS, CCA, CED, 2-1, 154, 3.

62 AGS, RGS, Sevilla, 23 de diciembre de 1484, fol 79.

63 AGS, RGS, Sevilla, 23 de diciembre de 1484, fol 81
} 
to entre los vecinos se efectuó a partir de una cantidad previamente fijada. A pesar de todo, la gestión de la Hermandad, vía encabezamiento, no solucionó todos los problemas recaudatorios, pues los intentos de fraude continuarían en los años siguientes.

Así por ejemplo, a mediados de los años noventa, la villa de Santa Marta y su tierra y el coto de Leiro, solicitaban la reducción de la cuantía en la que estaban encabezados. Concretamente, la villa de Santa Marta señalaba que se sentía agraviada por la cantidad que se le había asignado en la contribución de la Hermandad, por lo que solicitaba una reducción de 120 vecinos en cada año. Tras comprobar que las quejas de estos lugares se basaban en falsas relaciones, el 10 de septiembre de 1494 los monarcas enviaban sus cédulas a estos lugares ordenando que continuasen contribuyendo como lo habían hecho en años anteriores. ${ }^{64}$

Pero además de estos, se cometieron otros intentos de fraude por parte de los propios oficiales de la Hermandad. En este sentido, el procurador del reino de Galicia exponía el caso de la gente que se reclutaba a caballo y a pie en el reino para hacer ejecución en los bienes de aquellas personas que no habían pagado la contribución de la Hermandad, pues una parte de esta gente, a pesar de no acudir a desempeñar sus funciones exigían el pago del salario. Para poner remedio a esta situación, los reyes exigían al gobernador López de Haro y al corregidor Sancho García del Espinar, el libramiento de los salarios de estas gentes única y exclusivamente en los bienes confiscados a los deudores de la Hermandad. ${ }^{65}$

En 1484 se adoptaron una serie de medidas que contribuyeron a perfilar algunos aspectos de la Hermandad gallega que anteriormente habían dado lugar a cierta confusión. Indudablemente, las decisiones adoptadas por los monarcas en este sentido contribuyeron a mejorar el funcionamiento de la institución, pero a pesar de todo, los problemas derivados de su establecimiento continuarían algunos años después. Ahora bien, pasada la década de los años ochenta, su funcionamiento había mejorado considerablemente, sobre todo en el plano económico y fiscal, lo que facilitó en buena medida la regularización de las contribuciones. No obstante, durante los años ochenta, todavía algunos concejos gallegos mostraban ciertas resistencias al pago, lo que explica que el 11 de abril de 1485, los reyes requirieran a los concejos del reino de Galicia, exigiéndoles el pago de la contribución de la Hermandad, que había sido prorrogada por tres años en la junta de Miranda celebrada en $1483 .{ }^{66}$

${ }^{64}$ AGS, CCA, CED, 1, 149, 3 y CED 1, 150, 2.

65 AGS, RGS, Sevilla, 23 de diciembre de 1484, fol 85.

66 AGS, RGS, Córdoba, 11 de abril de 1485, fol 211. 
Sabemos por otra parte, que en 1485 la villa de Vivero debía algunas cantidades correspondientes a la contribución de la Hermandad de años pasados. El 15 de abril de este año, los reyes exigían al concejo de Vivero el pago de las deudas contraídas hasta agosto de 1484, así como todo lo correspondiente a los años inmediatamente posteriores. ${ }^{67} \mathrm{Y}$ en esta misma fecha, apremiaban a la ciudad de Santiago para que pagase los cuatro reales de la Hermandad de Galicia según se había acordado en la villa de Pinto. 68

Por lo general, las dificultades a la hora de llevar a cabo la recaudación de la contribución de la Hermandad fueron mayores en las tierras de señorío. Así por ejemplo, sabemos que el conde de Lemos, don Rodrigo Osorio, impedía a los alcaldes de la Hermandad entrar en sus tierras para proceder a la recaudación, a pesar de haber sido uno de los primeros nobles gallegos que habían apoyado decididamente el establecimiento de la Hermandad en el reino. El 14 de abril de 1485, los reyes exigían al conde consentir a los oficiales de la Hermandad usar de sus oficios y pagar la contribución de la Hermandad. ${ }^{69}$

Entre las medidas adoptadas por los Reyes Católicos a mediados de los años ochenta para afianzar el correcto funcionamiento de la Hermandad, cabe mencionar también el envío del contador Juan de Arévalo en 1486, para poner al día las cuentas de la Hermandad y saldar las deudas pendientes. ${ }^{70}$ No obstante, ésta y otras medidas adoptadas por los reyes para solucionar las dificultades derivadas de la recaudación de la Hermandad resultaron insuficientes, pues los problemas recaudatorios continuarían años después, sobre todo los que generaban los títulos de hidalguía, exentos del pago de la contribución, o los que se derivaban de la exención que disfrutaban los vasallos de órdenes militares, especialmente aquellos que se situaban en la jurisdicción de la orden de Santiago. Este era el caso de los vecinos de Toral, que se negaban a pagar la contribución de la Hermandad que les exigía el conde de Lemos, alegando estar exentos por ser vasallos de la orden de Santiago. $^{71}$

El hecho de que las irregularidades en el pago de la contribución de la Hermandad continuaran años después, fue motivo suficiente para que también se prolongara la acción de los oficiales reales en el reino, tratando de solucionar muchos de estos problemas. De ahí que en 1487, se enviara de nuevo al contador Juan de Aré-

\footnotetext{
67 AGS, RGS, Córdoba, 15 de abril de 1485, fol 226.

68 AGS, RGS, Córdoba, 15 de abril de 1485, fol 238.

69 AGS, RGS, Córdoba, 14 de abril de 1485, fol 209.

70 AGS, RGS, Medina del Campo, 22 de marzo de 1486, fol 182.

71 AGS, RGS, Palacios de Valduerna, 23 de octubre de 1486, fol 93.
} 
valo con determinadas instrucciones para supervisar las cuentas de la contribución de la Hermandad. ${ }^{72}$

Dos años después, el 26 de marzo de 1489, se comisionaba de nuevo al gobernador en el reino de Galicia, Diego López de Haro, para resolver el caso planteado por Juan Castañón y sus consortes, que se quejaban de los pechos que les exigía Fernando de Madrid, recaudador de la Hermandad en el obispado de Lugo, siendo hidalgos de solar conocido. ${ }^{73} \mathrm{Y}$ del mismo modo, el 8 de septiembre de 1489, se encargaba a López de Haro resolver la demanda que Vasco Rodríguez tenía pendiente con el concejo de Pinedo, que trataba de hacerle pagar la contribución de la Hermandad, siendo hidalgo y habiendo participado en el sitio de Baza. ${ }^{74}$

En muchos casos, los repartimientos de la gente de guerra también fueron objeto de determinados abusos por parte de los ejecutores de la Hermandad. Precisamente en 1492, los reyes encargaban al contador Arévalo hacer pesquisa sobre los perjuicios ocasionados por los ejecutores de la Hermandad a los vecinos de las provincias de Betanzos y La Coruña en los repartimientos de guerra. ${ }^{75}$ En relación con los repartimientos de peones de guerra, la documentación deja constancia del envío de 1.000 peones al reino de Sicilia en 1495, que debían ser pagados con cargo a la contribución de la Hermandad. Al parecer, algunos de estos peones que habían cobrado el sueldo de guerra no habían acudido a La Coruña para embarcar en las cuatro naos de Vizcaya que debían salir de armada con destino Sicilia. El 21 de julio de 1495, los reyes encargaban al gobernador López de Haro y al contador Juan de Arévalo, averiguar quienes habían sido los peones que habían cobrado sueldo de guerra y no habían acudido a La Coruña para embarcar en la armada de Vizcaya, y una vez sabida esta información, confiscar los bienes de aquellas personas que hubieran cometido el fraude. ${ }^{76}$ Un año antes, en septiembre de 1494 , en un nuevo intento de solucionar los conflictos surgidos en torno a la contribución de la Hermandad, los reyes habían ordenado al gobernador López de Haro y al contador Juan de Arévalo, realizar encabezamiento e iguala de lo que debían pagar las ciudades, villas y lugares, cotos y feligresías del reino de Galicia por la contribución de la Hermandad. ${ }^{77}$

72 AGS, RGS, Salamanca, 29 de enero de 1487, fol 49

73 AGS, RGS, Medina del Campo, 26 de marzo de 1489, fol 214

74 AGS, RGS, Real de Baza, 8 de septiembre de 1489, fol 204

75 AGS, RGS, Zaragoza, 20 de septiembre de 1492, fol 60

76 AGS, CCA, CED, 2-1, 97, 2.

77 AGS, RGS, Segovia, 10 de septiembre de 1494, fol 137 
A pesar de todo, los abusos y extorsiones por parte de los oficiales de la Hermandad persistieron hasta las vísperas de la desarticulación de la propia institución en 1498. En 1497, eran los vecinos de la tierra de Ribadulla los que protestaban contra Pedro Siso, regidor de Santiago y cogedor de la Hermandad, que había entrado en el lugar de Ribadulla y su tierra cometiendo todo tipo de excesos. ${ }^{78}$ Este mismo año, los oficiales de la casa de la moneda de La Coruña tenían pleito entablado con el concejo de la ciudad sobre el pago de la contribución de la Hermandad. Así, el 7 de octubre de 1497, el rey Fernando encargaba al gobernador, alcaldes mayores y al corregidor de La Coruña el cumplimiento de la sentencia y carta ejecutoria que disponía que los monederos debían pechar y pagar la contribución de la Hermandad. ${ }^{79}$

\subsection{Las cuentas de la Hermandad. Ingresos y Gastos.}

A pesar de todos los obstáculos que supuso el establecimiento de la Hermandad en Galicia, parece que a finales de los años ochenta esta institución se encontraba ya plenamente consolidada, incluso en el plano fiscal, aún cuando no faltan noticias sobre ciertas resistencias y algunos intentos de fraude en el pago de la contribución. Pero dejando al margen algunos casos aislados, cabe suponer que durante estos años, la contribución de la Hermandad se habría ido regularizando, aunque para finales de los años ochenta, no dispongamos de datos seriados que nos informen sobre las cuantías recaudadas por este concepto. Será preciso esperar hasta 1490 para disponer de los primeros datos relativos a los ingresos y gastos que generaba la contribución de la Hermandad, lo que nos permitirá conocer en que medida estos ingresos contribuyeron a incrementar el volumen global de ingresos de la Hacienda Regia y cual fue el valor relativo de la contribución con respecto a los ingresos ordinarios recaudados durante estos años. Y por otra parte, las cuentas de la Hermandad nos permitirán precisar muchos aspectos en relación con los distintos capítulos del gasto: salarios, sueldos, tenencias, acostamientos, libranzas, malhechores, salarios y descargos de tesoreros etc.. Ahora bien, antes de entrar a detallar las cuentas de la Hermandad, conviene recordar que en el reino de Galicia, el pago de estos tributos se efectuaba con un año de retraso con respecto a Castilla. Sabemos también que los pagos de la contribución de la Hermandad se realizaban por períodos anuales que se iniciaban el 15 de agosto y finalizaban en la misma fecha del año siguiente. Así por ejemplo, el trienio 1490-93 en las cuentas de Castilla se identifica con el período comprendido entre el 15 de agosto de 1489 y el 15 de agosto

78 AGS, RGS, Medina del Campo, 22 de junio de 1497, fol 235

79 AGS, RGS, Valladolid, 7 de octubre de 1497, fol. 215 y CCA-Pueblos, leg 6, f. 339. 
de 1492 en el reino de Galicia. Por consiguiente, las cuentas de la denominada "quinta prorrogación" en Galicia, que exponemos a continuación, correspondían a los años octavo, noveno y décimo de la Hermandad castellana. ${ }^{80}$

Tabla 8.- Contribución de la Hermandad. Reino de Galicia (1490-93) $)^{\mathbf{8 1}}$

\begin{tabular}{|c|c|c|c|c|c|c|}
\hline Provincia & $1489-90(\mathrm{rls})$ & $(m r s)$ & 1490-91 (rls) & (mrs) & 1491-92(rls) & (mrs) \\
\hline Santiago & 63.368 & 1.964 .408 & 63.976 & 1.983 .256 & 68.904 & 2.136 .024 \\
\hline La Coruña y & 29.849 & 925.319 & 30.312 & 939.672 & 29.660 & 919.460 \\
\hline Betanzos & & & & & & \\
\hline Mondoñedo & 14.926 & 462.706 & 15.216 & 471.696 & 14.943 & 463.233 \\
\hline Lugo & 50.608 & 1.568 .848 & 50.690 & 1.571 .390 & 51.364 & 1.592 .284 \\
\hline Orense & 37.116 & 1.150 .596 & 37.184 & 1.152 .704 & 37.300 & 1.156 .300 \\
\hline $\begin{array}{l}\text { Deudas de los } \\
\text { años pasados }\end{array}$ & 3.075 & 95.325 & & & & \\
\hline Total: & 195.867 & 6.167 .202 & 197.378 & 6.118 .718 & 197.162 & 6.112.333 \\
\hline
\end{tabular}

La sexta prorrogación de la Hermandad en Galicia abarcaba los tres años comprendidos entre el 15 de agosto de 1492 y el 15 de agosto de 1495. Para este período, no contamos con datos numéricos que nos permitan estimar el reparto porcentual que se efectuó en las provincias gallegas, y del mismo modo, tampoco es posible conocer el valor exacto del cargo que se le hizo al recaudador en cada uno de estos años. La única noticia que tenemos es relativa al valor global de los ingresos de la Hermandad para todo el trienio, que sumó un total de 18.235.920 mrs., lo que nos sitúa en una media anual de 6.078.640 mrs., una cantidad muy aproximada a la de los años anteriores. ${ }^{82}$

${ }^{80}$ Buena parte de la documentación conservada en el Archivo General de Simancas sobre las cuentas de la Hermandad ha sido recientemente publicada por LADERO QUESADA, M.A.: "La Hermandad en Galicia 1490-98”....op cit, pp. 240-287 y GARCÍA ORO, J.: Galicia en los S. XIV y XV, op cit, vol I, p. 339.

81 AGS, CMC, $1^{\text {a }}$ época, legs 128 y 134, publicados por LADERO QUESADA, M. A.: "La Hermandad en Galicia 1490-98"...op cit, p.14. Conviene destacar que en los años noveno (1491-92) y décimo (1492-93) se sumaron al cargo del recaudador determinadas cuantías en concepto de deudas de años anteriores. Concretamente en el año noveno se añadían 3.200 reales al cargo por las deudas de los años anteriores y el año siguiente 7.544 reales. Ladero Quesada señala como estas partidas aparecen tachadas en la documentación por lo que no deben tenerse en cuenta. No obstante, aparecen otras copias relativas al valor de los ingresos de la Hermandad de Galicia que revelan que al menos en el año décimo (1492-93) si se cargaron los maravedíes correspondientes a deudas de años anteriores sumando el cargo un total de $6.346 .196 \mathrm{mrs}$. Veáse AGS, CMC, $1^{\text {a }}$ época, leg 18 publicado por GARCÍA ORO, J.: Galicia en los $S$. XIV y XV...op cit, vol I, p.339.

82 AGS, CMC, $1^{a}$ época, leg 43, publicado en LADERO QUESADA, M.A.: "La Hermandad en Galicia 1490-98”...op cit, p. 24. 
No obstante, la contribución de las distintas provincias gallegas a la Hermandad en estos años, puede ser estudiada a partir del repartimiento de peones de 1495 que se efectuó con el fin de enviar una armada al reino de Sicilia y fue costeado con cargo a la contribución de la Hermandad. El repartimiento de peones de 1495 constituye una fuente de información similar a la contribución de la Hermandad en el reino, teniendo en cuenta que cada provincia estaba obligada a contribuir con una cuantía de maravedíes proporcional a la que le había sido asignada en la contribución de la Hermandad. No cabe duda de que el reclutamiento de 1.000 peones para embarcar en la armada de Vizcaya con destino Sicilia supuso un gran esfuerzo económico para las cuatro provincias gallegas, pues la cantidad asignada, unos 5.400.000 mrs., se aproximaba mucho al valor global de la contribución de la Hermandad del reino de Galicia en cada año. Con el fin de aliviar la carga fiscal que el repartimiento de peones suponía para el reino de Galicia, los reyes eximieron al reino del pago de una tercera parte de esta cantidad, de manera que, descontada esta tercera parte del cargo inicial y otras suspensiones de menor importancia, finalmente se hacía cargo al receptor de un total de 3.618 .204 mrs. y 14 c., distribuidos por provincias fiscales, en las proporciones que a continuación se detalla. ${ }^{83}$

Tabla 9.- Repartimiento de peones por vía Hermandad. Reino de Galicia(1495) ${ }^{84}$

\begin{tabular}{l|rrrr}
\hline Provincias & Vecinos & Cuantías $($ rls $)$ & Cuantías $(\boldsymbol{m r s})$ & \% \\
\hline Santiago y Tuy & 16.060 & 37.473 & 1.161 .673 & 32,10 \\
Lugo & 13.241 & 30.895 & 957.765 & 26,47 \\
Orense & 9.545 & 22.271 & 690.421 & 19,08 \\
Coruña y Betanzos & 7.524 & 17.566 & 544.546 & 15,05 \\
Mondoñedo & 3.647 & 8.509 & 263.799 & 7,29 \\
\hline Total: & $\mathbf{5 0 . 0 1 7}$ & $\mathbf{1 1 6 . 7 1 4}$ & $\mathbf{3 . 6 1 8 . 2 0 4}$ & $\mathbf{1 0 0}$ \\
\hline
\end{tabular}

La séptima prorrogación de la Hermandad en Galicia abarcaba el período comprendido entre el 15 de agosto de 1495 y el 15 de agosto de 1498. Para estos años disponemos de algunas cifras relativas al cargo que se le exigió al recaudador de la contribución, muy similar al de años anteriores, pues nos consta que en el año 1495-96 se recaudaron 6.087.408 mrs. por este concepto y los años 1496-97 y

${ }^{83}$ Las suspensiones a las que nos referimos sumaron un total de 58.020 mrs. y 10 cornados. Esta cifra incluía los descuentos por "el tercio de los 375 vecinos de Santiago y 43 excusados de la obra de su catedral", "dos excusados del monasterio de San Martín de Mondoñedo", "siete vecinos de Sarria" y "los doscientos vecinos cargados a la tierra del Bollo en la provincia de Orense" Véase LADERO QUESADA, M.A.: "La Hermandad en Galicia 1490-98"...op cit, p. 274.

${ }^{84}$ LADERO QUESADA, M. A.: “La Hermandad en Galicia 1490-98”... op cit, pp. 273-274 
1497-98, 6.050 .000 mrs. respectivamente. ${ }^{85}$ El último año de vigencia de la Hermandad conocemos el reparto detallado de las cuantías con las que contribuyó cada una de las provincias gallegas, lo que nos permite hallar, una vez más, el reparto proporcional.

Tabla 10.- Ingresos. Hermandad. Reino de Galicia. 1497-98 86

\begin{tabular}{l|rrr}
\hline Provincias & Cuantías $(\boldsymbol{r l s})$ & Cuantías $(\boldsymbol{m r s})$ & $\mathbf{\%}$ \\
\hline Santiago y Tuy & 62.532 & 1.938 .492 & 32,12 \\
Lugo & 52.632 & 1.631 .592 & 27,04 \\
Orense & 36.204 & 1.122 .324 & 18,60 \\
La Coruña y Betanzos & 29.296 & 908.176 & 15,05 \\
Mondoñedo & 13.968 & 433.008 & 7,17 \\
\hline Total & $\mathbf{1 9 4 . 6 3 2}$ & $\mathbf{6 . 0 3 3 . 5 9 2}$ & $\mathbf{1 0 0}$ \\
\hline
\end{tabular}

Las cantidades arriba expuestas nos permiten comprobar que el reparto cuantitativo de la contribución de la Hermandad en las provincias gallegas el año 1497-98 apenas difiere del que se efectuó durante los años 1490-93 o el que se había realizado para el repartimiento de peones en 1495. En líneas generales, podemos afirmar que los ingresos de la Hermandad se mantuvieron estables a lo largo de todo el período, sufriendo pequeñas alteraciones que apenas tienen transcendencia.

Tabla 11.- Ingresos de la Hermandad. Reino de Galicia (1490-98) (mrs)

\begin{tabular}{|cc|}
\hline Año/s & Cuantía \\
\hline $1489-90$ & 6.167 .202 \\
$1490-91$ & 6.118 .718 \\
$1491-92$ & 6.112 .333 \\
$1492-93$ & 6.078 .640 \\
$1495-96$ & 6.087 .408 \\
$1496-97$ & 6.050 .000 \\
$1497-98$ & 6.050 .000 \\
\hline
\end{tabular}

85 AGS, CMC, $1^{\text {a }}$ época, leg 43, publicado en LADERO QUESADA, M.A.: "La Hermandad en Galicia 1490-98"... op cit, p. 34. Para el último de los años de este período, 1497-98, contamos con otra información que nos proporciona unas cifras ligeramente inferiores a las aportadas por este autor. La diferencia es mínima, unos 6.033 .592 mrs. (194.632 reales) que apunta García Oro, frente a los 6.050.000 mrs. aportados por el profesor Ladero. Véase AGS, CMC, $1^{\mathrm{a}}$ época, leg 71, sin foliar.

86 Datos extraídos de AGS, CMC, $1^{\text {a }}$ época, leg 71, sin foliar. 
El estudio detallado de la distribución del gasto con cargo a la contribución de la Hermandad nos permite afirmar que en el reino de Galicia, los ingresos procedentes de dicha contribución se dedicaron fundamentalmente al mantenimiento de la propia institución y al pago de sus oficiales. Así, sabemos que con excepción de los corregidores, cuyo pago corría a cargo de las ciudades, casi todos los salarios de los oficiales enviados a Galicia y determinados sueldos militares se pagaron con cargo a la contribución de la Hermandad. A los capítulos del gasto mencionado se añadían otros como el mantenimiento de tenencias, pago de acostamientos, cantidades destinadas a la persecución de malhechores, salarios de los tesoreros de la Hermandad, descargos a tesoreros y libranzas, partidas del gasto, estas dos últimas, que englobaban diversos conceptos. Las cantidades dedicadas a las distintas partidas del gasto entre los años 1489-90 y 1497-98 han sido estudiadas con detalle por el profesor Ladero, de manera que no parece necesario insistir aquí en estas cuestiones. ${ }^{87}$

En 1498, último año de vigencia de la Hermandad, las cuentas de la Hermandad ponen de manifiesto las necesidades económicas del reino, debido fundamentalmente a las costosas campañas que la monarquía mantenía en territorio italiano. Por este motivo, el rey encargaba al gobernador Fernando de Vega, recaudar todas las deudas que el reino de Galicia tenía pendiente de años anteriores.

Sabemos, por otra parte, que a finales de los años noventa, la contribución de la Hermandad estaba a cargo del tesorero Alonso Gutiérrez de Madrid, que percibía de salario una blanca por cada real recaudado. Este año de 1498, el rey encargaba a Fernando de Vega pagar los salarios de los ejecutores, receptores, alcaldes y otros oficiales de la Hermandad, de la cuantía correspondiente al salario del tesorero Alonso Gutiérrez, que éste año había sumado un total de 97.316 mrs. Ahora bien, la mencionada cantidad resultaba insuficiente para hacer frente al pago de los salarios de los oficiales reales, que este año ascendieron a un total de $169.005 \mathrm{mrs}$. , de manera que era preciso librar el resto, 71.689 mrs., en el cargo principal de la Hermandad. 88

Pero además de estos 71.689 mrs. destinados al pago de oficiales de la Hermandad, en 1498 se apuntaban otras partidas del gasto más cuantiosas en el cargo principal de la Hermandad. Así por ejemplo, nos consta que este año se libraron a Pedro Álvarez de la Serna, 25.000 mrs. correspondientes al salario de

87 LADERO QUESADA, M.A.: “La Hermandad en Galicia 1490-98”...op cit, pp. 262-267 y 278281. Algunos porcentajes a partir de los datos que proporciona el profesor Ladero y otros detalles del gasto en mi tesis doctoral; Hacienda y gobierno de los Reyes Católicos..., op cit, pp. 678-683.

88 AGS, CMC, 1 a época, legs 69 y 71, sin foliar. 
seis meses en el desempeño del oficio de contador y oficial de la Hermandad. Entre los agraciados en el reparto de los ingresos de la Hermandad se encontraban también los principales poderes políticos del momento, como el conde de Lemos, que recibía 100.000 mrs. anuales a partir de la merced real que había obtenido en 1481, como compensación a su colaboración en el proceso de implantación de la Hermandad en el reino de Galicia. Otras partidas del gasto de las que tenemos noticia este mismo año fueron los $29.000 \mathrm{mrs}$. que se libraron al conde de Ribadeo, o los 30.672 mrs. librados al tesorero Alonso de Morales para el pago de algunos gastos que habían quedado pendientes de años anteriores. Pero sin duda, las mayores cuantías libradas con cargo a los ingresos de la Hermandad fueron las que se entregaron al tesorero Morales en dos partidas, de 2.938.260 mrs. y 2.818.249 mrs., que se destinarían en su mayor parte a atender el pago de sueldos de militares, acostamientos, tenencias y persecución de malhechores. 89

Tabla 12.- Data. Hermandad. Reino de Galicia (1498)

\begin{tabular}{l|r}
\hline Partida del gasto & Cuantía $($ Mrs $)$ \\
\hline Pedro Álvarez de la Serna & 25.000 \\
El conde de Lemos & 100.000 \\
El conde de Ribadeo por merced & 29.000 \\
Salarios de receptores, ejecutores, alcaldes de la Hermandad y otras cosas & 71.689 \\
Al tesorero Alonso de Morales y a Fernando de Caviedes en su nombre & 2.938 .260 \\
Al tesorero Alonso de Morales y a Juan de Pereda en su nombre & 2.818 .249 \\
Al tesorero Alonso de Morales y a Juan de Pereda en su nombre & 30.672 \\
\hline Total data: & $\mathbf{6 . 0 1 2 . 8 7 0}$ \\
\hline
\end{tabular}

En líneas generales, podemos afirmar que el tardío establecimiento de la Hermandad en el reino de Galicia, la posterior puesta en marcha de su aparato recaudatorio y la tardía regularización de los ingresos recaudados por este concepto, hicieron de la contribución de la Hermandad gallega un modelo de impuesto muy distinto al que se recaudaba en otras partes de la Corona de Castilla, pues en este último caso, los ingresos derivados de la contribución de la Hermandad se orientaron fundamentalmente a costear las campañas que desembocarían en la conquista de Granada.

89 AGS, CMC, $1^{\text {a }}$ época, leg 71, sin foliar y LADERO QUESADA, M.A.: "La Hermandad en Galicia 1490-98"...op cit, pp. 36-43. 
Pero quizá lo más significativo del detalle del gasto de la contribución de la Santa Hermandad, sean las mercedes que determinados miembros de la nobleza gallega recibieron con cargo a las rentas de la contribución. Ya nos hemos referido al caso del conde de Lemos, don Rodrigo Osorio, que percibía una cuarta parte de los ingresos que generaba la Hermandad de su tierra, en virtud de la merced concedida a su abuelo, Pedro Álvarez Osorio, al haber apoyado el establecimiento de la Santa Hermandad en tierras gallegas. La cantidad que ingresaba el de Lemos por este concepto era de 100.000 mrs. anuales, pues el 10 de septiembre de 1494, los reyes ordenaban al contador Juan de Arévalo, el libramiento de 200.000 mrs. al conde de Lemos, por lo que le era debido de los años $1492-93$ y $1493-1494 .{ }^{90}$ Según consta en la documentación, este mismo año de 1494, se libraban al de Lemos otros 100.000 mrs. en cuenta de los 610.000 mrs. que se le habían mandado librar por cédula real de un total de 1.000.000 de maravedíes que el conde debía percibir para saldar los daños ocasionados en Ponferrada. ${ }^{91}$ Entre los miembros de la nobleza titulada que recibieron este tipo de mercedes se encontraba también el conde de Monterrey, que recibía 100.000 mrs. anuales con cargo a la contribución de la Hermandad de su tierra desde el año 1493-94 en adelante. ${ }^{92}$ Y por otra parte, los ingresos de la Hermandad se orientaron también al pago de las mercedes y acostamientos de diversos caballeros del reino de Galicia. Entre éstas últimas mercedes, tenemos noticia de los 30.000 mrs. que se libraban en 1494 a García de Sarmiento, señor de Sobroso. ${ }^{93}$

\section{LOS SERVICIOS EXTRAORDINARIOS DEL REINO DE GALICIA (1500-1517)}

Es bien sabido que el origen de los servicios extraordinarios aprobados en Cortes que se recaudan durante todo el siglo XVI se localiza en los últimos años del reinado de los Reyes Católicos, cuando los monarcas se vieron obligados a allegar nuevos recursos económicos con los que hacer frente a las diversas necesidades del reino y a las campañas que mantenían en el exterior, que tuvieron como escenario principal el reino de Nápoles. Sobre la situación de la Hacienda Real en este período, son varios los autores que coinciden en señalar que, desde mediados de los años noventa, los ingresos ordinarios que se recaudaban en Castilla ya no resultaban

\footnotetext{
90 AGS, CCA, CED, 1, 149, 2.

91 AGS, CCA, CED, 1, 149, 1.

92 AGS, CCA, CED, 1, 87, 6, CED, 1, 94, 1 y CED, 1, 151, 3.

93 AGS, CCA, CED, 1, 151, 3.
} 
suficientes para satisfacer las necesidades de un reino que buscaba continuamente la anexión de nuevos territorios. ${ }^{94}$

Desarticulados los órganos centrales de la Hermandad en 1498, se llevaba a cabo el repartimiento de un nuevo servicio extraordinario. Y es precisamente a partir de 1500, con el restablecimiento de los servicios extraordinarios votados en Cortes, cuando se puede hablar de una plena regularización en el pago de estos tributos por parte del reino de Galicia, sucediéndose los repartimientos de servicios de manera continua hasta el año 1517. Por lo que se refiere a Galicia, sabemos que los intereses de dicho reino se exponían en las Cortes por medio de los procuradores de la ciudad de Zamora, aunque no fueran los procuradores zamoranos los encargados de recaudar el servicio en el reino, pues para esta función se había nombrado al gobernador, Fernando de Vega. ${ }^{95}$

La convocatoria de Cortes de Sevilla en el año 1500 era la primera en aprobar el reparto de servicios extraordinarios con posterioridad a las Cortes de Madrigal de 1476. En ellas se pretendía recaudar las sumas necesarias para hacer frente a los gastos derivados de la política exterior que incluían las dotes asignadas a las infantas Isabel y Catalina, para contraer matrimonio con los herederos del reino de Portugal e Inglaterra, como prueba evidente de las negociaciones diplomáticas que los Reyes Católicos habían iniciado con dichos reinos, cuyo fin último era eliminar la presencia francesa en territorio italiano y muy especialmente, en el reino de Nápoles. Así, en 1496 se concertaban los matrimonios de las infantas Isabel y Catalina. En primer lugar, se acordaba el matrimonio de la infanta Isabel con el rey de Portugal, Manuel I. Isabel moría al dar a luz a su hijo Miguel, motivo por el cual los reyes acordaron el matrimonio de su hija María con el rey viudo de Portugal. Y por otra parte, se pactaba el matrimonio de la infanta Catalina con el heredero del trono inglés, Arturo, que tendría lugar en 1501.96

Las Cortes celebradas en 1500 aprobaron la concesión de 150.000.000 de maravedíes para la dote de las infantas, una cantidad de la que 146.000.000 de marave-

94 Sobre el origen y recaudación de servicios de Cortes durante los primeros años del s. XVI véase los trabajos de CARANDE THOVAR, R.: Carlos V y sus banqueros, Barcelona, 2000 y ULLOA, M.: La Hacienda Real de Castilla en el reinado de Felipe II, Fundación Universitaria Española, 1977 y en especial los de J. Carretero Zamora: Cortes, monarquía, ciudades. Las Cortes de Castilla a comienzos de la época moderna (1476-1515), Madrid, 1988, "Los servicios de Cortes y las necesidades financieras de la monarquía castellana (1500-1517)" en Cuadernos de Historia Moderna y Contemporánea, 8 (1987), pp. 31-56 y "La Hacienda Real de Castilla en 1503 y 1505. Algunos datos cuantitativos" en Cuadernos de Historia Moderna, $\mathrm{n}^{\circ}$ 13, 1992, pp. 169-197, "Los servicios de las Cortes de Castilla en el s. XVI" en Cuadernos de Historia Moderna, no 21, 1998, pp.15-58.

95 CARRETERO ZAMORA, J.: Cortes, monarquía, ciudades...op cit, p. 98.

96 DE ANDRÉS DÍAZ, R.: "La fiscalidad regia extraordinaria en el último decenio de Isabel I" en Cuadernos de Historia Moderna, $\mathrm{n}^{\circ}$ 13, Editorial Complutense, Madrid, p. 151 
díes se dedicaron en exclusiva al pago de la dote, mientras que los otros 4.000.000 de maravedíes se entregaron a los procuradores en pago de salario y ayuda de costa. La cuantía global votada en Cortes debía ser repartida en toda la Corona de Castilla durante los años 1500-02: 54.000.000 de maravedíes en 1500, 50.000.000 en 1501 y 46.000 .000 en 1502 .

Para cada uno de estos años, los reyes encargaban a su gobernador, Fernando de Vega, efectuar la recaudación de la cuantía asignada al reino de Galicia. Conocemos algunos aspectos acerca de los mecanismos empleados para llevar a cabo la recaudación del servicio de estos tres años, sobre todo porque dicha recaudación se efectuó tomando como referencia el repartimiento de peones de 1495. Así por ejemplo, sabemos que los alcaldes, cuadrilleros y cogedores de la Hermandad se encargaron de recaudar la cuantía asignada a cada una de las cinco provincias del reino, con los quince maravedíes al millar que debían ser entregados al receptor. Nos consta también que la entrega del servicio debía ser efectuada en dos plazos: el primero, fijado a finales del mes de junio, con la mitad del importe y el segundo, con la otra mitad, a finales de octubre. Las cantidades asignadas al reino de Galicia en el repartimiento del servicio extraordinario de 1500 , fueron muy elevadas con respecto a otras provincias fiscales de la Corona de Castilla, pues del total de 54.000.000 de maravedíes fijados para el conjunto de la Corona de Castilla, el reino de Galicia debía contribuir con 6.128.000 mrs., lo que venía a suponer exactamente el $11,34 \%$ del total.

En los dos años siguientes, la contribución de Galicia en el servicio extraordinario presenta los mismos niveles con respecto al conjunto de la Corona de Casti1la. Concretamente en 1501, el reino de Galicia contribuía con 5.674.074 mrs. de los 50.000.000 de maravedíes repartidos para toda Castilla, lo que nos sitúa de nuevo en unas proporciones del 11,34\% del total repartido. Y el último año del trienio, 1502, se repartían 5.151.209 mrs. en el reino de Galicia, de los 46.000.000 de maravedíes recaudados en Castilla, una cantidad que representaba el 11,1\%.97

No cabe duda de que la contribución del reino de Galicia en los servicios extraordinarios durante estos tres años resultaba excesiva, aún teniendo en cuenta que a principios del siglo XVI, la mitad norte de Castilla presentaba una situación económica mucho más favorable que las áreas septentrional y meridional del reino. Según los datos ofrecidos por el profesor Carretero Zamora, en los repartimientos de servicios extraordinarios de la primera mitad del siglo XVI, la mitad norte acu-

97 AGS, EMR, leg 77, fol 37, leg 78, fols 19, 20 y 38 (1500), leg 78, fol 96, leg 80, fol 353 (1501), leg 77 fol 134, leg 78 fol 153, leg 85 fol 38, leg 85-II fol 1129 (1502) 
mulaba el 53,83\% del total asignado para el conjunto de la Corona de Castilla, mientras que la meseta sur y Andalucía presentaban coeficientes más modestos $(23,34 \%)$ y $(22,83 \%)$ respectivamente, debido posiblemente al predominio de señoríos jurisdiccionales, sobre todo de órdenes militares, sometidas a una menor presión fiscal. En el caso particular del reino de Galicia, Carretero Zamora sostiene que la contribución del reino en los servicios de Cortes estaría sobrevalorada, quizá por la resistencia que todavía a estas alturas el reino ofrecía al pago de servicios..$^{98}$

De nuevo en 1502, los reyes convocaban Cortes en Toledo "para jurar a los ylustrísimos princesa doña Juana, primogénita heredera destos nuestros reynos y señoríos y príncipe don Felipe, como su legítimo marido, archiduques de Austria y duques de Borgoña etc..”. Las Cortes de Toledo de 1502 otorgaron 50.000 .000 de maravedíes de servicio para este fin, de los cuales $1.333 .333 \mathrm{mrs}$. y $2 \mathrm{c}$. se dedicaron al pago de salarios y ayudas de costa de los procuradores. Es posible también que del importe que se debía recaudar este año en concepto de servicio extraordinario, se hubiera dedicado una parte a costear las victoriosas campañas de Gonzalo Fernández de Córdoba en la segunda guerra de Nápoles, aunque si así fue, esta cantidad habría resultado insuficiente, ya que el año siguiente se convocaban Cortes para este mismo fin. Las Cortes de Madrid de 1503 votaron un total de 150.000.000 de maravedíes que debían ser repartidos entre los años (1504-06) con una cuantía de 50.000 .000 de maravedíes en cada año, de los que $2.666 .666 \mathrm{mrs}$. y 4 c. se entregaban a los procuradores en pago de salarios.

Finalmente se acordaba repartir las cuantías aprobadas en las Cortes de Toledo (50.000.000) y de Madrid (150.000.000) entre los años 1503-06, aunque en caso de necesidad sería posible repartir y recaudar el servicio correspondiente a estos cuatro años entre 1503 y 1504, como de hecho sucedió. Esta urgencia con la que los reyes decidieron recaudar los servicios votados por las Cortes de Toledo y Madrid, se debió fundamentalmente a la deuda que la monarquía había contraído como consecuencia de las campañas que se habían llevado a cabo entre los años 1501 y 1502 en el reino de Nápoles. Con el fin de saldar deudas y efectuar los correspondientes pagos de tropas y acostamientos, se llevaba a cabo el repartimiento de los servicios otorgados por las Cortes de Toledo y de Madrid en los años 1503 y 1504, correspondiendo a cada uno de estos años 100.000 .000 de maravedíes.

Así, de los 100.000.000 de maravedíes que debían ser repartidos en toda la Corona de Castilla, en 1503, correspondieron al reino de Galicia, 11.641 .732 mrs.,

98 CARRETERO ZAMORA, J.: "Los servicios de las Cortes de Castilla en el siglo XVI" op cit, pp. 18-19. 
5.820.866 mrs. por cada uno de los años 1503 y 1504, lo que nos sitúa una vez más en unas proporciones similares a las de los años anteriores (11,64\%). En 1504, se efectuaba el repartimiento de las cuantías correspondientes a los años 1505 y 1506. Este año Galicia debía contribuir con 11.417.046 mrs., 5.708.523 mrs. para cada uno de estos años, una cantidad que representaba exactamente el 11,41\% del volumen global asignado para toda la Corona de Castilla. ${ }^{99}$

La documentación de la Escribanía Mayor de Rentas, nos permite conocer algunos aspectos acerca de la resistencia que ofrecieron determinados lugares al pago de servicios extraordinarios. Así, sabemos que en la contribución del servicio de los años 1503 y 1504, junto a los seis partidos fiscales del reino de Galicia, debía contribuir la villa de Cacabelos, situada en la actual provincia de León y la tierra de Aguiar, próxima a la ciudad de Orense. El primero de estos lugares, formaba parte de los dominios señoriales del prelado compostelano, de manera que al igual que el resto de los abadengos del arzobispado de Santiago, estaba obligado a contribuir en los servicios de Cortes. Por lo que se refiere a las obligaciones fiscales de la tierra de Aguiar, sabemos que, durante la primera mitad del siglo, la villa y su tierra habían pertenecido al prelado compostelano, hasta que en 1458, el arzobispo don Rodrigo de Luna la cediera en calidad de "feudo perpetuo" a don Juan Pimentel. Sin embargo y a pesar de la cesión del señorío de Aguiar a la casa de Pimentel, las alcabalas de la villa y su tierra quedarían vinculadas al arzobispo de Santiago, tal y como se pone de manifiesto en la documentación de la segunda mitad del XV.

Ahora bien, en el caso de los repartimientos de servicios extraordinarios de los años 1503 y 1504, la villa de Cacabelos y la tierra de Aguiar estaban obligadas a contribuir con el partido fiscal de Villafranca del Bierzo. En 1504 los concejos de Cacabelos y Aguiar tenían pleito entablado con la villa de Villafranca, a causa de los servicios de Cortes que se negaban a pagar alegando tener ciertos privilegios que les eximían del pago. Sin embargo, los argumentos expuestos por ambos concejos no debieron dar los resultados esperados, pues el 17 de octubre de este año, emanaba del consejo una cédula real en la que se ordenaba al corregidor de la villa de Ponferrada apremiar a las villas de Cacabelos y Aguiar para que pagasen y contribuyesen con la villa de Villafranca la parte correspondiente al servicio de 1503. ${ }^{100}$

En 1506, se otorgaba un nuevo servicio de Cortes. Este año, los reyes don Felipe y doña Juana convocaron Cortes en la ciudad de Valladolid. Las Cortes de Valla-

99 AGS, EMR, leg 77, fol. 199, leg 78, fols. 227 y 338, leg 93, fol. 124 y leg 99, fol. 38 (1503), leg 77 , fol. 282 , leg 78 , fol. 339 , leg 96 , fol. 132 y leg 99 , fol. 39. 
dolid otorgaron 100.000.000 de maravedíes para ayuda de los grandes gastos derivados de la vuelta de los reyes a Castilla, así como para pagar las deudas que el reino tenía pendientes: "así de las cosas del estado como descargo del ánima de la reina mi señora que aya santa gloria"

En un principio, se determinó repartir el servicio aprobado en las Cortes de Valladolid en los años 1507-1509, aunque finalmente dicho reparto tendría lugar durante los años 1510-11, sobre todo porque parecía menos gravoso para el conjunto de la población castellana, que en los años inmediatamente anteriores había padecido los efectos derivados de las continuas pestes y esterilidad de los campos. Por consiguiente, el repartimiento del servicio extraordinario otorgado por las Cortes de Valladolid de 1506 tenía lugar en los años 1510 y 1511, en cada uno de los cuales se repartieron un total de 50.000 .000 de maravedíes para el conjunto de la Corona de Castilla. El repartimiento efectuado en 1510 asignaba 6.100.000 mrs. al reino de Galicia, una cuantía que representaba el 12,2\% del total fijado para el conjunto de la Corona de Castilla, lo que nos sitúa en unas proporciones muy similares a las alcanzadas durante el trienio 1500-02. Las condiciones en las que se efectuaba el repartimiento acordaban la entrega del servicio en tres plazos, el primero de los cuales debería hacerse efectivo a finales del mes de abril, un segundo plazo fijado a finales de agosto y el tercero y último que debería tener lugar en diciembre de este mismo año.

En el repartimiento efectuado en 1511, el reino de Galicia contribuyó con 6.039.000 mrs., de los 50.000.000 de maravedíes asignados para Castilla, lo que venía a suponer exactamente el $12,07 \%$ del total. En octubre de 1509 y enero de 1511, la reina Juana otorgaba la carta de receptoría correspondiente a cada uno de estos dos años a favor del gobernador Fernando de Vega, con el fin de que acudiese con las cuantías correspondientes al servicio extraordinario ante los receptores. ${ }^{101}$

En 1512 se celebraban Cortes en Burgos. En esta ocasión, los procuradores de las ciudades castellanas votaron un servicio de 154.000.000 de maravedíes a repartir en los años 1512-14 con el fin de atender las necesidades del reino, especialmente las relativas a la Iglesia: " para que los procuradores viesen y tratasen, platicasen, consintiesen y otorgasen cualesquier cosas que viesen ser cumplideras a servicio de Dios nuestro señor y defensión de su iglesia y pro y bien común destos

100 AGS, EMR, leg 78, fol. 338.

101 AGS, EMR, leg 77, fol. 408 y leg 78, fol. 427(1510) y leg 77, fol. 473 y leg 78, fol. 538 (1511). 
dichos mis reinos, especialmente sobre las necesidades que la iglesia romana nuestra madre y maestra de todos al presente tiene..". ${ }^{102}$

De la suma mencionada, 150.000.000 de maravedíes se dedicaban estrictamente a cubrir las necesidades de la Iglesia, mientras que otros 4.000.000 de maravedíes se destinarían al pago de salarios y ayudas de costa de procuradores. En cada uno de estos tres años (1512-14), el reino de Galicia contribuirá con unas cuantías de maravedíes muy aproximadas a las de los años anteriores. Así, sabemos que de los 54.000.000 de maravedíes repartidos para toda Castilla en 1512, 6.228.000 mrs. correspondieron al reino de Galicia. Los años 1513 y 1514, el reino de Galicia contribuía en el pago del servicio con unas cantidades algo inferiores, 5.770.240 mrs. y 5.758.702 mrs., de los 50.000.000 de maravedíes asignados para toda Castilla en cada uno de estos dos años, unas cantidades que representaban aproximadamente el $11,5 \%$ del total. ${ }^{103}$

De nuevo, en 1515 se celebraban Cortes en la ciudad de Burgos. Este año, los procuradores de las ciudades y villas castellanas votaban 154.000.000 de maravedíes "para ayuda a los grandes gastos y necesidades que al presente se ofrecían hacer para las cosas del servicio de la iglesia y nuestro como para la conservación $y$ defensión de los dichos nuestros reinos". Al igual que en el trienio anterior, de la cuantía global votada en Cortes, 4.000.000 de maravedíes se destinaban al pago de costas y salarios de los procuradores. El servicio votado en las Cortes de Burgos de 1515 se repartía entre los años 1515-17, con unas cuantías de 54.000.000 de maravedíes para toda la Corona de Castilla el primer año y 50.000.000 de maravedíes en cada uno de los dos años siguientes. La contribución de Galicia en el servicio extraordinario de cada uno de estos años se sitúa una vez más en torno al 11,5\% del total de las contribuciones de Castilla. Las cifras que manejamos, relativas a la contribución del reino de Galicia en el pago del servicio extraordinario en cada uno de estos años son de $5.758 .702 \mathrm{mrs}$. para 1515 y $5.767 .071 \mathrm{mrs}$. para cada uno de los años 1516 y 1517. Las condiciones en las que se efectuaba el repartimiento del servicio extraordinario fijaban los plazos de entrega a finales de los meses de abril, agosto y diciembre de cada año. El 19 de julio de 1515, la reina Juana libraba su carta de receptoría en el gobernador y justicia mayor del reino de Galicia, con el fin de que acudiese con las cuantías correspondientes al servicio del reino de Galicia ante el receptor, Fernando de Cuenca. ${ }^{104}$

102 AGS, EMR, leg 78 fol. 668 .

103 AGS, EMR, leg 78, fols 609 y 668 (1512) y leg 77, fol 668, leg 78, fol 788 (1513) y leg 78, fol 861 (1514).

104 AGS, EMR, leg 77 fol 795, 853 y 919 (1515-17) 
Tabla 8.- Servicios de Cortes. Reino de Galicia (1500-17)

\begin{tabular}{|ccc|}
\hline Año & Cuantía & \% \\
\hline 1500 & 6.128 .000 & 11,34 \\
1501 & 5.674 .074 & 11,34 \\
1502 & 5.151 .209 & 11,10 \\
1503 & 5.820 .866 & 11,64 \\
1504 & 5.820 .866 & 11,64 \\
1505 & 5.708 .523 & 11,41 \\
1506 & 5.708 .523 & 11,41 \\
1510 & 6.100 .000 & 12,20 \\
1511 & 6.039 .000 & 12,07 \\
1512 & 6.228 .000 & 11,53 \\
1513 & 5.770 .240 & 11,54 \\
1514 & 5.770 .240 & 11,54 \\
1515 & 5.758 .702 & 11,51 \\
1516 & 5.767 .071 & 11,53 \\
1517 & 5.767 .071 & 11,53 \\
\hline
\end{tabular}

Las cifras relativas al servicio extraordinario repartido en Galicia durante los años 1500-17, pone de manifiesto el crecimiento económico que había experimentado el reino de Galicia en el último cuarto del siglo XV, que se observa de forma mucho más clara en la evolución que presentan los impuestos ordinarios. Pero por otra parte, merece la pena llamar la atención sobre la plena regularización que se alcanzó en el reino de Galicia en el pago de los servicios extraordinarios. Ya nos hemos referido a las elevadas cuantías que en los repartimientos del servicio extraordinario de estos años fueron asignadas al reino de Galicia, lo que en opinión del prof. Carretero Zamora debe ser interpretado como una posible sobrevaloración de las cuantías asignadas al reino de Galicia ante las posibles resistencias que pudiera presentar al pago de los servicios, tal y como había sucedido durante buena parte del siglo XV. No obstante, unos años después, las averiguaciones del reinado de Carlos I reducían notablemente la participación del reino de Galicia en los servicios de Cortes. ${ }^{105}$

105 CARRETERO ZAMORA, J.: Cortes, monarquía, ciudades...op cit, p. 98 


\section{CONCLUSIÓN}

Una reflexión final acerca de lo que los servicios extraordinarios significaron en el reino de Galicia durante el siglo XV, nos obliga a referirnos a la importancia que dichos tributos tuvieron en relación con el conjunto de impuestos ordinarios del reino.

Al margen de las peculiaridades que presenta la recaudación del pedido en el reino de Galicia por las dificultades que entrañaba su recaudación, cabe suponer que durante todo el siglo XV, la población gallega se vio sometida a unos niveles de presión fiscal muy considerables, sobre todo aquella que habitaba en tierra de señorío, que era la mayoría, y estaba obligada a satisfacer al señor una gran cantidad de tributos de carácter señorial, la mayoría de los cuales se pagaban en especie. El caso más significativo entre los señoríos gallegos es el de la Iglesia de Santiago, cuyos habitantes debían hacer frente a un amplio conjunto de tributos de carácter señorial y eclesiástico, que se recaudaban en el marco de las mayordomías. Entre estos tributos señoriales, destaca especialmente el servicio extraordinario que el prelado compostelano recaudaba en la tierra de Santiago, que proporcionaba notables beneficios a la hacienda arzobispal, y cuyos repartimientos venían a coincidir, al menos durante la década de los años treinta, con el reparto del pedido real. ${ }^{106}$ Pero además de estos tributos, los habitantes de la tierra de Santiago tenían que atender al pago de impuestos ordinarios -alcabalas, diezmos y alfolíes-, y extraordinarios.

La comparación de los valores del pedido de 1442 con los relativos a los tributos ordinarios de este mismo año, pone de manifiesto que la cuantía de pedido repartida entre las distintas provincias fiscales del reino de Galicia se aproxima bastante al valor que este año alcanzaron las contribuciones ordinarias. Así, sabemos que las rentas reales ordinarias del reino de Galicia sumaron en 1442 un total de 4.113.868 mrs. (514.233 rls.), una cuantía algo superior a la del pedido recaudado este año, que sumó un total de 3.581 .080 mrs. (447.635 rls). ${ }^{107}$ Para el año 1445,

106 RODRÍGUEZ GONZÁLEZ, A.: O tumbo vermello de don Lope de Mendoza, Santiago, 1995, f. 114v, p. 162. Este libro de recaudación de la Hacienda Arzobispal Compostelana, fechado en 1435, nos permite constatar que la población de la tierra de Santiago que habitaba en los denominados lugares reguengos contribuía al mismo tiempo en el servicio que repartía la Hacienda Arzobispal y en los pedidos reales que recaudaba la Hacienda Real en dichos lugares.

107 Sobre la evolución que presentan las rentas reales ordinarias en estos años véase mi artículo "La Hacienda Real en Galicia en tiempos de Juan II", En la España Medieval, vol 31, 2008, pp, 413-474. 
las cuantías son muy similares a las que acabamos de exponer. Este año, el volumen de tributos ordinarios recaudados en concepto de alcabalas, diezmos de la mar y alfolíes se calcula en unos $4.425 .907 \mathrm{mrs}$. (553.236 rls), frente a los 4.724.291 mrs. (590.536 rls.) repartidos en concepto de pedido. ${ }^{108}$ Teniendo en cuenta las cuantías de pedido mencionadas, cabe suponer las dificultades que debió encontrar la población gallega para hacer efectivo el pago del pedido, ya que por otra parte, tenía que hacer frente a unas elevadas cuantías de tributos ordinarios, además de atender a las exigencias de la fiscalidad señorial.

Ya en el reinado de los Reyes Católicos, a principios de los años noventa, la situación había cambiado favorablemente para la Hacienda Regia, sobre todo debido al notable incremento que las rentas habían experimentado desde principios de la década de los setenta, como consecuencia inmediata de las medidas hacendísticas adoptadas por los reyes, y del auge que la actividad comercial había alcanzado durante estos años. En este sentido, cabe suponer que el esfuerzo económico que habría tenido que hacer la población del reino de Galicia para satisfacer la contribución de la Hermandad en estos años, habría sido mucho menor que el de años anteriores. A pesar de todo, las cuantías con las que la población gallega debía contribuir continuaban siendo elevadas, no sólo las relativas a la contribución de la Hermandad, sino también las derivadas de las rentas reales ordinarias. Así, sabemos que durante estos años, las cuantías asignadas al reino de Galicia en la contribución de la Hermandad se situaban en unos 6.000 .000 de maravedíes, mientras que los ingresos derivados de las contribuciones ordinarias ya superaban los 10.000.000 de maravedíes.

Unos años después, los servicios aprobados por las Cortes del reino para el conjunto de la Corona de Castilla, asignarían unas cuantías de maravedíes al reino de Galicia que representaban unos porcentajes del $11 \%$ del total de las contribuciones fijadas para Castilla. Las contribuciones del reino de Galicia en los servicios extraordinarios aprobados por las Cortes del reino a partir del año 1500 fueron las mayores de todo el período, aunque por estos años las cantidades que la Hacienda Real recaudaba en concepto de tributos ordinarios eran mucho más elevadas, pues venían a suponer tres veces más que las cuantías recaudadas en concepto de servicios extraordinarios. Las cifras que manejamos para estos años ponen de manifiesto que

108 Las cantidades mencionadas en concepto de pedido corresponden a un solo repartimiento, cuando en realidad se efectuaron dos. Las cuantías correspondientes a los segundos repartimientos llevados a cabo en cada uno de estos años no han de ser tenidos en cuenta en este apartado, pues como ya hemos señalado, deber ser interpretados como uno de los mecanismos de cobro de deudas de años anteriores. 
los ingresos derivados de las contribuciones ordinarias superaban con mucho los derivados de los tributos extraordinarios. Así por ejemplo, en el año 1500 correspondieron al reino de Galicia $6.128 .000 \mathrm{mrs}$. en el pago del servicio extraordinario, mientras que, por otra parte, la Hacienda Real recaudaba un total de 15.326.952 mrs. en concepto de tributos extraordinarios. Tres años después, nos encontramos con unas cantidades similares, unos ingresos para la Hacienda Real de 5.820.866 mrs. por el servicio extraordinario del reino de Galicia frente a los $16.170 .730 \mathrm{mrs}$. derivados de la recaudación de los impuestos ordinarios.

Estas reflexiones acerca de la evolución que experimentaron los servicios extraordinarios en el reino de Galicia durante el siglo XV, y las dificultades que entrañó su recaudación durante buena parte de esta centuria, pone de manifiesto la importancia de las medidas hacendísticas adoptadas por los Reyes Católicos, sobre todo a partir de 1476, con el establecimiento de la Santa Hermandad, que dio lugar a la plena regularización hacendística en el reino. Una vez más, la documentación de carácter fiscal, constituye un fiel reflejo de la política emprendida por los Reyes Católicos en el reino de Galicia que permitió restaurar la paz y el ejercicio efectivo del poder real, consiguiendo la plena regularización de las contribuciones ordinarias y extraordinarias. 